\section{Assessment of best management practices for nutrient cycling: A case study on an organic farm in a Mediterranean-type climate}

\author{
S.M. Smukler, A.T. O’Geen, and L.E. Jackson
}

\begin{abstract}
The effectiveness of best management practices (BMPs) designed primarily to protect surface water quality was assessed on a farm certified for organic tomato production to consider potential environmental quality and production tradeoffs. The BMPs included winter cover crops typically used in organic farming to cycle nutrients and reduce stormwater runoff; tailwater ponds designed to capture runoff; and tailwater return systems, which recycle runoff back to the field. The study took place at a 44 ha $(108 \mathrm{ac})$ farm in Yolo County, California, over a two-year period. Monitoring throughout the winter rainy season showed cover crops successfully reduced runoff and loads of several constituents during the storm events, when compared to fallow. Total discharge was reduced by $44 \%$, total suspended solids was reduced by $83 \%$, ammonium was reduced by $33 \%$, and dissolved organic carbon (DOC) was reduced by $58 \%$. Estimates of leaching losses of DOC in the cover cropped fields, however, were $70 \%$ higher than the fallow fields in the winter rainy season and were $30 \%$ higher than the fallow fields in the summer irrigation season. During the summer irrigation season, the tailwater pond alone was highly effective in reducing losses of total suspended solids and volatile suspended solids to the neighboring riparian zone by $97 \%$ and $89 \%$, respectively. The tailwater pond had no effect on dissolved reactive phosphorous and actually increased concentrations of nitrate-nitrogen $\left(\mathrm{NO}_{3}^{-}-\mathrm{N}\right)$ in effluent by $40 \%$ and DOC by $20 \%$. As was expected, the $\mathrm{NO}_{3}^{-}-\mathrm{N}$ leaching measured by anion exchange resin bags and nitrous oxide emissions measured by static closed chambers was higher for the tailwater pond than the fallow field. Despite these differences, losses via $\mathrm{NO}_{3}{ }^{-} \mathrm{N}$ leaching and nitrous oxide emissions accounted for only 24.7 and $0.48 \mathrm{~kg} \mathrm{~N} \mathrm{ha}^{-1} \mathrm{y}^{-1}\left(22.0\right.$ and $\left.0.40 \mathrm{lb} \mathrm{N} \mathrm{ac}^{-1}\right)$, respectively, for the entire farm, even including ponds and ditches. When field and plot values were extrapolated to the entire tomato production area to understand the relative potential tradeoffs, results indicate that BMPs could be implemented without an impact on tomato marketable yields; the tailwater pond's higher nitrous oxide emissions would not significantly increase the overall emissions for tomato production given its relatively small size; and using tailwater ponds in combination with cover crops would decrease total suspended solids (TSS) losses compared to cover crops alone, with only minor increases in $\mathrm{NO}_{3}^{-}-\mathrm{N}$ and DOC losses. Adding a tailwater return system to this combination of BMPs could help minimize these $\mathrm{NO}_{3}{ }^{-} \mathrm{N}$ and DOC losses. Use of cover crops with a tailwater pond and tailwater return system are a combination of BMPS that can thus be recommended for organic production when considering multiple environmental outcomes.
\end{abstract}

Key words: best management practices—cover crops — nutrient cycling — organic farmingtailwater pond-tradeoffs

Farmers who aim to produce food and fiber with fewer environmental impacts need a better understanding of the potential tradeoffs among management

options (Jordan et al. 2007). California has begun regulating nonpoint source pollution through mandatory runoff monitoring established by the Irrigated Lands
Regulatory Program. The monitoring is designed to identify at-risk watersheds and implement best management practices (BMPs), which synchronize the availability of nutrients with crop demand, prevent their movement off farm, or capture and recycle them. In California's Mediterranean-type climate, runoff commonly occurs during the heavy winter rains of the cool nonproduction season and during irrigation operations in the hot dry summer production season. In furrow-irrigated vegetable production, surface runoff can exceed 50\% of applied water if poorly managed (Bjorneberg et al. 2002). Best management practices have been mainly designed and implemented for high-input conventional farms but are also important for the rapidly expanding organic vegetable production sector. It is unclear, however, if current BMPs designed to protect water quality will perform in the context of California's even more recent environmental mandate, AB32, to reduce greenhouse gas emissions.

Organic systems are limited to nonsynthetic inputs (e.g., compost, manures, and cover crops) and require mechanical cultivation for weed control, and thus, can be especially sensitive to asynchronous nutrient availability, leading to crop yield reduction and sediment and nutrient losses (Berry et al. 2002; Watson et al. 2002; Willson et al. 2001). Nitrogen losses via surface runoff and leaching can be relatively low in organic systems (Sileika and Guzys 2003; Aronsson et al. 2007), but phosphorus losses can be a concern when the use of manures for meeting nitrogen (N) crop demands results in soil phosphorus that exceeds crop demand (Nelson and Janke 2007). Sediment losses are also a concern given that chemical control of weeds is not an option to reduce erosion risk in organic systems (Shipitalo and Edwards 1998).

Winter cover crops, annual or perennial plantings grown during California's rainy season, are a key nutrient cycling management tool for organic production and are a recommended BMP for protecting water-

Sean M. Smukler is an assistant professor in the faculty of Land and Food Systems at the University of British Columbia, Vancouver, British Columbia. Anthony T. O'Geen is a soil resource specialist and Louise E. Jackson is a professor and specialist in Cooperative Extension in the Department of Land, Air and Water Resources, University of California, Davis, California. 
ways for any type of agricultural production system. Winter cover crops have been shown to decrease N leaching (Jackson et al. 1993; Tonitto et al.2006; Wyland et al.1996), increase soil organic matter (Kong et al. 2005; Lee and Phillips 1993), provide subsequent crops with residue-derived nutrients (Tonitto et al. 2006), and effectively reduce erosion (Dabney 1998; Mutchler and Mcdowell 1990) and stormwater runoff (Joyce et al. 2002).

Winter cover crops may, however, result in some unintended environmental impacts or even reduce short-term agricultural productivity, but these tradeoffs have not been adequately evaluated. For example, higher soil $\mathrm{C}$ and $\mathrm{N}$ availability from cover crops may increase soil carbon dioxide $\left(\mathrm{CO}_{2}\right)$ and nitrous oxide $\left(\mathrm{N}_{2} \mathrm{O}\right)$ emissions (Baggs et al. 2000; Johnson et al. 2005). These emissions, without significant concomitant $\mathrm{C}$ sequestration, could make organic farming a net contributor to global warming (Jackson et al. 2004; Sarkodie-Addo et al. 2003). Increased $\mathrm{C}$ availability may also contribute to dissolved organic carbon (DOC) in surface runoff and leachate, causing problems for drinking water treatment. Should winter rains extend into the spring, direct seeding into the winter cover crop or winter cover crop incorporation can be delayed. Delay of seeding or incorporation can result in reduced yields of the subsequent summer crop (Clark et al. 1999) and large quantities of undecomposed residue that can affect summer furrow irrigation. While cover crops may increase soil infiltration and water holding capacity (Dabney et al. 2001), additional BMPs may be required to ensure that runoff leaving organic farm fields is not negatively impacting adjacent waterways.

Tailwater ponds, another BMP recommended for agriculture, may be an effective compliment to winter cover crops to reduce soil and nutrient losses (Hartz 2006). Smallscale ponds can be combined with pumping systems that return tailwater (i.e., effluent) to the field for irrigation purposes. By recycling effluent, tailwater return systems can reduce runoff loses to the environment and improve irrigation efficiency, thus reducing costs (Schwankl et al. 2007). The effectiveness of tailwater ponds and tailwater return systems to protect water quality in the context of California agriculture is largely assumed (Schwankl et al. 2007) and, for organic farms, is virtually unknown.
Beyond the impact on water quality, potential environmental tradeoffs need to be better understood before tailwater return systems are constructed on a wide scale. High water content and anaerobiosis (Harrison and Matson 2003; Harrison et al. 2005; Johnson et al. 2005) in soils in and around the ponds may result in a substantial increase in a farm's $\mathrm{N}_{2} \mathrm{O}$ production. Tailwater ponds may also lead to downward seepage of nutrients, which can contaminate groundwater, depending on a pond's management (e.g., improper sealing). Installation of the ponds also requires land to be taken out of production, reducing the overall yield of a farm.

Many of these potential tradeoffs result from ecological processes that occur at various scales over varying time periods, making accurate assessment challenging. To evaluate tradeoffs, it is therefore necessary to select indicators of these processes that can be monitored in a way that can capture spatial and temporal variation effectively (DeFries et al. 2004; Dale and Polasky 2007). The specific objectives of this study were to (1) quantify and monitor the magnitude, timing, and pathway of nutrient losses from organic processing tomato (Solanum lycopersicum) production in California's Central Valley; (2) evaluate the effectiveness of cover crops, tailwater ponds, and tailwater return systems to minimize these losses; and (3) assess the relative environmental quality and agricultural production tradeoffs and potential synergies that should be considered when implementing these BMPs.

\section{Materials and Methods}

Site Description. The 44 ha $(108 \mathrm{ac})$ farm, located at the western edge of the Sacramento Valley (figure 1) has been in organic tomato (Solanum lycopersicum L.) production since 1993 and relies mainly on cover crops and compost for nutrient inputs (table 1). The farm is located on an alluvial fan along the riparian corridor of Chickahominy Slough, on a Tehama silt loam, (fine-silty, mixed, superactive, thermic Typic Haploxeralfs) (Andrews 1972).

The farm is divided into two fields: North Field is 26.5 ha $(65.5 \mathrm{ac})$, and South Field is $14.7 \mathrm{ha}(36.3 \mathrm{ac})$. These fields are in an alternate year rotation between oat (Avena sativa) production and processing tomatoes (figure 2). The fields have a slope of $1 \%$ to $1.5 \%$. Irrigation and winter runoff drain into a network of ditches that occupy 0.02 ha
$(0.05 \mathrm{ac})$ at the eastern end of the farm and then drain into tailwater ponds that occupy 0.06 ha $(0.15 \mathrm{ac})$, where a pump returns the water to the top of the field to be mixed with either pumped groundwater or water delivered through California's aqueduct system and reused for crop irrigation.

The Mediterranean-type climate has hot, dry, nearly rainless summers and cool, wet winters, typically with several larger storm events that can be $>20 \mathrm{~mm} \mathrm{~d}^{-1} \quad>0.79$ in day $\left.^{-1}\right)$. Thus, the results of this two-year experiment are reported by two seasons, either Irrigated (April through October) or Rainfed (November through March). The average minimum and maximum air temperatures between the beginning of the experiment in March of 2005 and its end in April of 2007 , were $8.7^{\circ} \mathrm{C}$ and $23.6^{\circ} \mathrm{C}$ $\left(47.6^{\circ} \mathrm{F}\right.$ and $\left.74.8^{\circ} \mathrm{F}\right)$, respectively. In the first year of the experiment (April 2005 to March 2006), rainfall was unusually high $(863 \mathrm{~mm}$ [34.0 in]), and in the following year (April 2006 to March 2007), rainfall was unusually low with $213 \mathrm{~mm}$ (8.4 in), compared to average precipitation $(508 \mathrm{~mm}$ [20.0 in]) for the previous five years. In fact, no runoff was recorded during the wet season of the second year (RainfedY2).

The experiment began in April of 2005, when a tomato crop was planted on the South Field (figure 2). At that time, the North Field was still in oats, planted the previous fall. After the tomatoes were harvested in the fall of 2005, the South Field was planted in oats, and the grower divided the North Field into sections to compare a mustard cover crop (Brassica nigra [L.] Koch) with winter fallow. In the spring of 2006, the mustard cover crop was mowed, incorporated by discing, and a tomato crop was planted across the entire North Field. In June 2006, the oats in the South Field were harvested and a summer cowpea (Vigna unguiculata [L.] Walp. ssp. unguiculata) cover crop was planted for only a month and then was incorporated by discing.

Field Sampling. Tomato yields were sampled within three days of the grower's harvest. To capture yield variability across the field, transects were oriented north-south of each main sampling plot $(393 \mathrm{~m}[1,289 \mathrm{ft}]$ in the North Field or $250 \mathrm{~m}$ [820 ft] in the South Field). Along each transect, a $1 \times 3 \mathrm{~m}^{2}$ $\left(3.28 \times 9.84 \mathrm{ft}^{2}\right)$ subplot was established at $30 \mathrm{~m}$ (98.4 ft) intervals (five or nine subplots depending on the width of the field). At each 


\section{Figure 1}

Location of the farm site, map of the farm, tailwater pond configuration and runoff sampling points. During Irrigated $Y_{1}$, sampling took place at (1) the main irrigation pipe and (2) tomato field discharge point using automated samplers of the South Field, and grab samples were taken at (3) the discharge point for the sediment trap of the South Field. During the Rainfed Y1 and Irrigated Y2 seasons, automated samplers collected discharge at (4) the exit point of the fallow section of the North Field, which was divided (dotted line) in two; (5) the exit point of the mustard cover crop section of the North Field; (6) the exit point for North Field discharge into the sediment pond; and subsequently, (7) the exit point of the tailwater pond, where the irrigation effluent is pumped back to the west end (top) of the North Field.

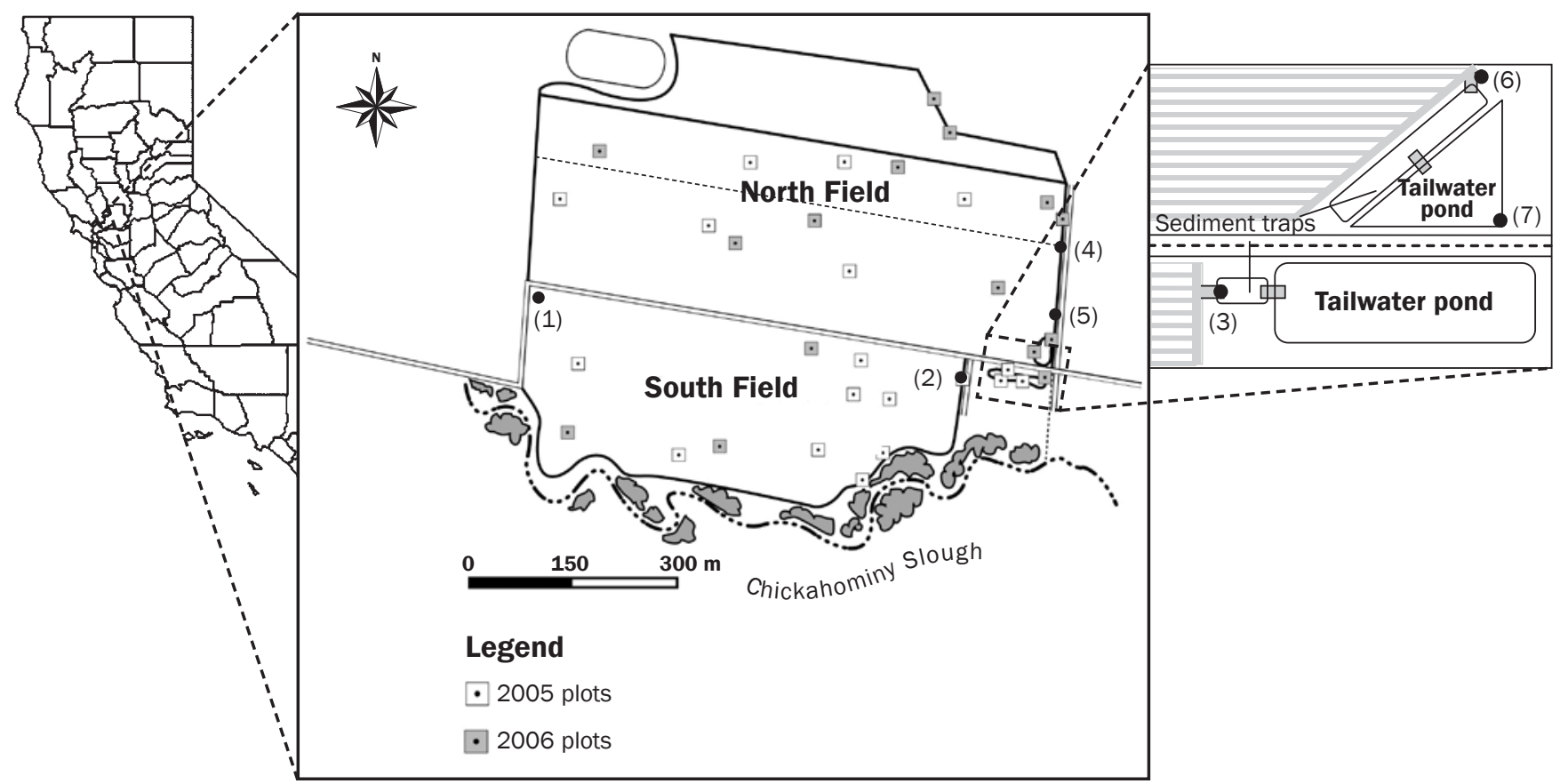

Table 1

Compost, weeds, and aboveground cover crop inputs for the 2006 tomato crop.

\begin{tabular}{|c|c|c|c|c|c|c|c|}
\hline Input & $\begin{array}{l}\text { Mass } \\
\left(\mathrm{Mg} \mathrm{ha}^{-1}\right)\end{array}$ & $\begin{array}{l}\begin{array}{l}\text { Total C } \\
\left(\mathrm{kg} \mathrm{ha}^{-1}\right)\end{array} \\
\end{array}$ & $\begin{array}{l}\begin{array}{l}\text { Total N } \\
\left(\mathrm{kg} \mathrm{ha}^{-1}\right)\end{array} \\
\end{array}$ & C:N ratio & $\begin{array}{l}\mathrm{NO}_{3}^{-}-\mathrm{N} \\
\left(\mathrm{kg} \mathrm{ha}^{-1}\right) \\
\end{array}$ & $\begin{array}{l}\text { P } \\
\left(\mathrm{kg} \mathrm{ha}^{-1}\right) \\
\end{array}$ & $\begin{array}{l}\mathrm{K} \\
\left(\mathrm{kg} \mathrm{ha}^{-1}\right) \\
\end{array}$ \\
\hline Compost & 15 & $2,892.3$ & 297.9 & 9.7 & 27.7 & 34.8 & 264.3 \\
\hline Fallow (weeds) & 1.7 & 712.1 & 12.8 & 55.8 & - & 4.1 & 22.6 \\
\hline Mustard cover crop & 5.2 & $2,236.0$ & 46.4 & 48.2 & - & 11.4 & 75.5 \\
\hline
\end{tabular}

Notes: $\mathrm{C}=$ carbon. $\mathrm{N}=$ nitrogen. $\mathrm{NO}_{3}{ }^{-} \mathrm{N}=$ nitrate-nitrogen. $\mathrm{P}=$ phosphorus.

$\mathrm{K}=$ potassium. $-=$ no data.

sampling point, individual tomato plants were cut at the base, and the fruit was separated by hand. Fruit quality was evaluated in the field by classification into split reds, pinks, greens, sunburn, mold or rot, blossom end rot, insect damage, and undamaged red tomatoes (USDA 1997). Marketable tomatoes were those considered likely to be harvestable by mechanized equipment, specifically, split red tomatoes, pink tomatoes, sunburn tomatoes, insect damaged tomatoes, and undamaged tomatoes. All weeds were identified to species and were harvested for aboveground biomass from each plot. Biomass of fruits, tomato vegetative material, and weed bio- mass were weighed in the field (fresh weight) and then were subsampled and dried at $60^{\circ} \mathrm{C}$ $\left(140^{\circ} \mathrm{F}\right)$, before being ground and analyzed for total $\mathrm{N}$, phosphorus, and potassium $(\mathrm{K})$ at the University of California Agriculture and Natural Resources Analytical Laboratory. The nutrient content of the mustard cover crop treatment was measured just before incorporation in March of 2006 (table 1).

The quantities of nutrients added to the fields through the incorporation of compost were estimated using the farmer's records of application rates and analysis of piles within a week of application. Compost piles were sampled randomly before incorporation and were analyzed for $\mathrm{N}$, phosphorus, and $\mathrm{K}$. Bulk density of the compost was measured using the core method (Blake and Hartge 1986). Compost for the 2005 crop was applied before the experiment started and was not analyzed.

Surface runoff and tailwater were monitored at the field scale ( $>10$ ha [ $>24.7 \mathrm{ac}]$ ) at catchment points (figure 1), while leachate and emissions of $\mathrm{CO}_{2}$ and $\mathrm{N}_{2} \mathrm{O}$ were monitored using a stratified random sampling approach at the plot level $\left(16 \mathrm{~m}^{2}[172\right.$ $\left.\mathrm{ft}^{2}\right]$ ). During the first season (Irrigated Y1), irrigation influent and field discharge were continuously monitored on the South Field using ISCO 6700 (Teledyne Technologies, Lincoln, Nebraska) autosamplers fitted with low-profile area velocity flow meters. The autosamplers collected a $250 \mathrm{~mL}$ (8.5 oz) subsample every $4 \mathrm{~h}$, whenever there was at least $5 \mathrm{~cm}$ ( 2 in) of water present in the channel or pipe, and composited subsamples daily.

The tailwater pond system utilized a two-stage treatment of water effluent from the drainage ditch. The first was a smaller sediment trap, and the second was a larger detention pond, after which water flowed 


\section{Figure 2}

Total monthly precipitation and irrigation and daily mean temperatures by season for the two-year experiment. The cool wet winters and warm dry summers shown here are typical of California's Mediterranean-type climate. The first rainfed season (Rainfed Y1) was an unusually wet winter, and the second rainfed season (Rainfed $\mathrm{Y}_{2}$ ) was an unusually dry winter. Corresponding timelines of the crop rotations for the North Field and South Field are illustrated below. The North Field was divided into two sections following oats in the fall of the first year. Irrigated $Y_{1}$ and Irrigated $Y_{2}$ refer to the irrigated crop growing seasons of both years.
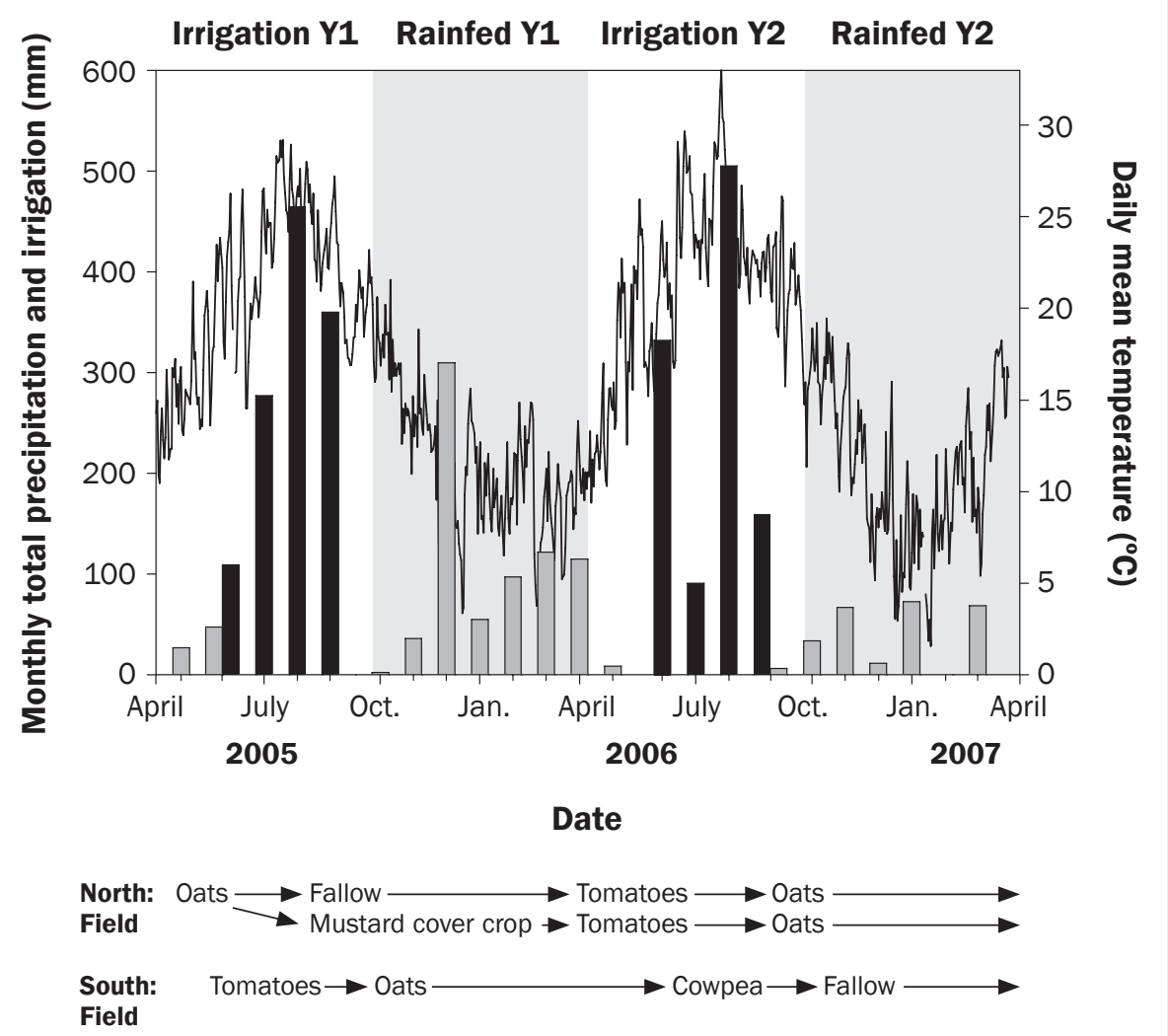

Legend

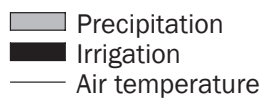

into the main tailwater pond (figure 1). In the first year, only the sediment trap was sampled as the effluent water exiting from the tailwater pond on the South Field was removed by subsurface pumping at the bottom of the pond, making it impossible to monitor. Effluent from the South Field sediment trap was sampled daily by hand (grab samples).

Each year autosamplers were positioned to collect runoff from the different fields and crop mixes (figure 1). Irrigation influent to the fields was monitored with daily grab samples, and irrigation flow rates were calculated using records of hourly pump use and mean flow rates for the pump system, as determined with autosamplers. Influent into the tailwater pond (water discharged from the field) was calculated from a weighted average of the flow from the autosampler in the two sections (tomatoes/mustard and tomatoes/ fallow). The remaining field area was not part of the cover crop trial. Discharge from this area was diverted from the experiment via an additional ditch and was excluded from runoff calculations.

Plots were selected in March of each year to monitor changes in soil properties, soil solution, soil $\mathrm{CO}_{2}$ and $\mathrm{N}_{2} \mathrm{O}$ emissions, and yields. Plots were stratified randomly in a geographic information system within the boundaries of the North Field, South Field, drainage ditches, and tailwater pond (figure
1). At the beginning of the experiment, six plots were established in each of the large sampling sites (North Field and South Field), and three were established in the smaller sites (drainage ditches and tailwater ponds). These plots were abandoned in irrigated year 2 (Irrigated Y2), and plots were rerandomized within each sampling site-this time including the new sites in the North Field, which was divided into the mustard cover crop and winter fallow treatments, each with three sampling plots. Thus in Irrigated Y2, three plots occurred in each site: North Field tomatoes/mustard, North Field tomatoes/ fallow, South Field, North Field drainage ditches, and North Field tailwater pond.

At the beginning of each of the four sampling seasons (figure 2), three soil cores (6.3 $\mathrm{cm}$ [2.48 in] diameter) were taken at random in each plot every $15 \mathrm{~cm}$ (5.9 in) to a depth of $75 \mathrm{~cm}$ (29.5 in), composited, and put on ice for analysis of ammonium $\left(\mathrm{NH}_{4}{ }^{+} \mathrm{N}\right)$ and nitrate-nitrogen $\left(\mathrm{NO}_{3}^{-}-\mathrm{N}\right)$ (see below for laboratory analysis methods). Soil from the 0 to 15 and 15 to $30 \mathrm{~cm} \mathrm{(0} \mathrm{to} 5.9$ and 5.9 to 11.8 in) depths was analyzed for an additional suite of soil properties (see below for laboratory analysis methods). Bulk density was determined at 0 to 6,9 to 15 , and 18 to $24 \mathrm{~cm} \mathrm{(0} \mathrm{to} 2.36,3.54$ to 5.91 , and 7.1 to 9.5 in) depths, using rings of $345 \mathrm{~cm}^{3}$ (21.1 $\left.\mathrm{in}^{3}\right)$ volume to remove intact soil cores (Blake and Hartge 1986).

Soil solute leaching was assessed for all sites in two ways: ceramic cup suction lysimeters (Soil Moisture Equipment Corp; Zoarelli et al. 2007) and anion exchange resin bags for cumulative $\mathrm{NO}_{3}^{-}-\mathrm{N}$ losses (Wyland and Jackson 1993). After sampling for soil inorganic $\mathrm{N}$ at the beginning of each of the four sampling seasons, $7.6 \mathrm{~cm}$ (3.0 in) diameter resin bags were buried at $75 \mathrm{~cm}$ (29.5 in). Resin bags were placed within a $1 \mathrm{~cm}(0.39$ in) deep polyvinyl chloride ring of the same inner opening diameter designed to protect the bag and facilitate collection and then were packed into a shelf dug into the side of augured hole. Resin bags were collected at the end of each season and were extracted with 2 molar potassium chloride, which was analyzed for $\mathrm{NO}_{3}^{-}-\mathrm{N}$. Resin (AG 1-X8) was assumed to recover $84.7 \%$ of the cumulated $\mathrm{NO}_{3}^{-}-\mathrm{N}$ losses up to a threshold of $3.7 \mathrm{~g}$ $\mathrm{NO}_{3}^{-}-\mathrm{N} \mathrm{kg}^{-1}$ resin $\left(0.74 \mathrm{oz} \mathrm{NO}_{3}^{-}-\mathrm{N} \mathrm{lb}^{-1}\right.$ ) (Wyland and Jackson 1993) or a maximum of $95 \mathrm{~kg} \mathrm{NO}_{3}^{-}-\mathrm{N} \mathrm{ha}^{-1}\left(84.6 \mathrm{lb} \mathrm{NO}_{3}^{-}-\mathrm{N} \mathrm{ac}^{-1}\right)$ for the size of resin bag used in this study. 
Lysimeters were installed to 30 and $60 \mathrm{~cm}$ (11.8 and 23.6 in) depths to capture the variability in movement of soil water given the potential asynchrony of irrigation or rainfall and sampling. A vacuum of $75 \mathrm{kPa}(0.74$ atm) was applied to the lysimeters and was sampled weekly during summer irrigation and winter rainfed seasons.

Cumulative leaching past the 30 and $60 \mathrm{~cm}$ (11.8 and 23.6 in) lysimeters was estimated by multiplying observed concentrations of analyzed constituents by calculated soil solution deep percolation (DP) for each sampling period, using the simplified one-dimensional water balance equation:

$\mathrm{DP}=\mathrm{I}-\mathrm{IR}+\mathrm{P}-\mathrm{ETc} \pm \mathrm{VR}$,

where $\mathrm{P}=$ precipitation $(\mathrm{mm})$; $\mathrm{I}=$ water applied by irrigation $(\mathrm{mm})$; IR $=$ water exiting the field as irrigation runoff; ETc $=$ crop evapotranspiration $(\mathrm{mm}) ; \mathrm{VR}=$ variation of soil water reserve, based on gravimetric soil moisture $\left(\theta_{\mathrm{m}}\right)$ measurements $(\mathrm{mm})$; and DP $=$ deep percolation (mm) (Wagenet 1986). Daily irrigation, runoff, and precipitation data were collected using the autosamplers. The ETc was modeled using the Basic Irrigation Scheduling (BIS) model for each crop (Snyder et al. 2007) using the crop coefficient $(\mathrm{Kc})$ and reference evapotranspiration (ETo). The ETo was calculated using the modified Penman-Monteith method (Allen et al. 1998), and climate data was acquired from a nearby weather station (California Irrigation Management Information System [CIMIS]). Values for Kc were determined using the BIS model. The VR was calculated from the change in gravimetric soil moisture between sampling periods. The water balance for drainage ditches was calculated using the differences in flow rates from the autosamplers that monitored the irrigation water exiting the different field sections. Calculations assumed similar ETc to the fields given that narrow ditches $(<20 \mathrm{~cm}$ [ $<7.9$ in] wide) were bordered by tomatoes on one side and weeds on the other.

Annual soil emissions of carbon dioxidecarbon $\left(\mathrm{CO}_{2}-\mathrm{C}\right)$ and nitrous oxide-nitrogen $\left(\mathrm{N}_{2} \mathrm{O}-\mathrm{N}\right)$ were estimated from gas samples taken randomly from the surface of beds between tomato plants and in ditches and tailwater ponds within each plot when water was not present, or if present, within $6 \mathrm{~cm}$ of water's edge. Gaseous emissions were measured one day each month. Gas samples of
$\mathrm{CO}_{2}-\mathrm{C}$ and $\mathrm{N}_{2} \mathrm{O}-\mathrm{N}$ were collected using cylindrical vented static chambers $12.3 \mathrm{~cm}$ (4.84 in) in diameter and $11.0 \mathrm{~cm}$ (4.3 in) tall with a total interior volume of 1,307 $\mathrm{cm}^{3}\left(79.8 \mathrm{in}^{3}\right.$ ) (Hutchinson and Livingston 1993). At the same time, $\mathrm{CO}_{2}-\mathrm{C}$ was also monitored using a LI-COR 8100-102 portable survey chamber $10 \mathrm{~cm}$ (3.94 in) in diameter (LI-COR Biosciences, Lincoln, Nebraska), which was placed within $30 \mathrm{~cm}$ (11.8 in) of the static chambers. LI-COR 8100 samples were taken and analyzed at three-minute intervals. The instrument has a measurement range of 0 to $3,000 \mathrm{ppm}$ and reported accuracy reading of $1.5 \%$ (LI-COR Biosciences, Lincoln, Nebraska). Polyvinyl chloride collars for the static chambers were pounded into the soil surface between 6 to $24 \mathrm{~h}$ before sampling and then were removed to avoid disturbance by farming operations. Nitrous oxide from vacutainers was analyzed on a gas chromatograph with a radioisotope nickel-63 $\left({ }^{63} \mathrm{Ni}\right)$ electron capture detector (HP 6890, Hewlett Packard, Palo Alto, California). Concentrations of $\mathrm{CO}_{2}-\mathrm{C}$ were determined from vacutainer samples using a gas chromatograph with a thermal conductivity detector (HP 5890, Hewlett Packard, Palo Alto, California).

Laboratory Analysis. Within 24 h, soil samples were homogenized in the laboratory on ice and were analyzed for gravimetric moisture and potassium chloride-extractable $\mathrm{NO}_{3}{ }^{-}-\mathrm{N}$ and $\mathrm{NH}_{4}{ }^{+}-\mathrm{N}$ colorimetrically (Foster 1995; Miranda et al. 2001). Soils sampled at the beginning of each year were air dried for further analysis. Electrical conductivity (EC) (Rhoades 1982) and $\mathrm{pH}$ were determined with a 1:1 ratio of soil to deionized water (USSL 1954). Air-dried soil samples and oven-dried plant samples were analyzed for total $\mathrm{C}$ and $\mathrm{N}$ using a dynamic flash combustion system coupled with a gas chromatograph (Department Agriculture and Natural Resources Analytical Lab 2007). Soils were also analyzed for Olsen phosphorus (Olsen and Sommers 1982) and soil texture by laser diffraction (Eshel et al. 2004).

All water samples were immediately put on ice and were transported back to the laboratory for filtering after each irrigation or rain event. Unfiltered samples were analyzed for EC and $\mathrm{pH}$. For runoff samples, to ensure thorough mixing of suspended solids, $50 \mathrm{~mL}(1.7 \mathrm{oz})$ was pipetted from the sample while it was being vortexed and then the 50 $\mathrm{mL}$ was suction filtered through preweighed
$0.7 \mu \mathrm{m}\left(2.76 \times 10^{-5}\right.$ in $)$ pore-size glass fiber filters, which were weighed and dried at $60^{\circ} \mathrm{C}\left(140^{\circ} \mathrm{F}\right)$. Filtered samples were frozen for temporary storage. Total suspended solids (TSS) were calculated from differences in prefilter and postfilter dry weights (Clesceri et al. 1998). Dried filters were then subsampled (cut in half), reweighed, placed in crucibles and ignited in a muffle furnace at $550^{\circ} \mathrm{C}\left(1,022^{\circ} \mathrm{F}\right)$ for 30 minutes. Volatile suspended solids were calculated from the difference in pre- and postignition of the dried half-filter weights. Water samples were analyzed for $\mathrm{NO}_{3}^{-}-\mathrm{N}$ and $\mathrm{NH}_{4}^{+}-\mathrm{N}$ dissolved reactive phosphate (DRP) colorimetrically (Murphy and Riley 1958), and DOC on a Dohrmann Phoenix 8000 UV-persulfate oxidation analyzer (Tekmar-Dohrmann, Cincinnati, Ohio).

Daily loads of constituents in runoff samples were calculated for influent and discharge from either composited autosampler samples or grab samples using a flow-weighted average. Thus, mean concentrations for each day were multiplied by the total flow for the day and were divided by the area of discharge. Daily loads were summed for the duration of each irrigation or storm event.

Management Tradeoff Analysis: To estimate the relative benefits, tradeoffs, and identify potential synergies of implementing BMPs for organic processing tomatoes, plot and field data for production and environmental indicators were extrapolated to the entire area of the farm that was in tomato production during rainfed year one (Rainfed Y1) and Irrigated Y2. Tomato production using a winter fallow (tomatoes/fallow) was contrasted with BMP options that include winter cover crops, winter cover crops and tailwater ponds, or winter cover crops, tailwater ponds, and a tailwater return system. Mean results for marketable tomato yield, TSS, $\mathrm{NO}_{3}^{-}-\mathrm{N}$, DRP, DOC leaching and/ or runoff loads, and $\mathrm{N}_{2} \mathrm{O}$ and $\mathrm{CO}_{2}$ soil emissions for the North Field, ditches and tailwater pond were multiplied by their respective areas, summed for the two seasons, and divided by their total summed areas. This produced a per hectare annual rate for each indicator. The $\mathrm{N}_{2} \mathrm{O}-\mathrm{N}$ was converted to $\mathrm{CO}_{2}$ equivalents using a conversion factor that takes into account emissions of $\mathrm{N}_{2} \mathrm{O}$ are 298 times greater than equal emissions of $\mathrm{CO}_{2}$ over 100-year time period (Forster et al. 2007). 


\section{Table 2}

Soil properties taken at the o to $15 \mathrm{~cm}$ and 15 to $30 \mathrm{~cm}$ depth for each of the sampling areas for the 2005 and 2006 seasons. Means and standard errors of two years of sampling are shown (sample size $=3$ to 6 per site).

\begin{tabular}{|c|c|c|c|c|c|c|c|c|c|c|}
\hline Site & $\begin{array}{l}\text { Depth } \\
\text { (cm) }\end{array}$ & $\begin{array}{l}\text { Bulk } \\
\text { density } \\
\left(\mathrm{g} \mathrm{cm}^{-3}\right)\end{array}$ & $\mathrm{pH}$ & $\mathrm{EC}\left(\mu \mathrm{S} \mathrm{cm} \mathrm{cm}^{-1}\right)$ & $\begin{array}{l}\text { Total N } \\
\left(\text { Mg ha }^{-1}\right)\end{array}$ & $\begin{array}{l}\text { Total C } \\
\left(\mathrm{Mg} \mathrm{ha}^{-1}\right)\end{array}$ & $\begin{array}{l}\text { Olsen-P } \\
\left(\mathbf{m g ~ k g}^{-1}\right)\end{array}$ & $\begin{array}{l}\text { Sand } \\
\left(\mathrm{g} \mathrm{kg}^{-1}\right)\end{array}$ & $\begin{array}{l}\text { Silt } \\
\left(\mathrm{g} \mathrm{kg}^{-1}\right)\end{array}$ & $\begin{array}{l}\text { Clay } \\
\left(\mathrm{g} \mathrm{kg}^{-1}\right)\end{array}$ \\
\hline South field & 0 to 15 & $1.2 \pm 0.0$ & $7.2 \pm 0.0$ & $138.4 \pm 18.5$ & $2.5 \pm 0.1$ & $21.9 \pm 1.3$ & $33.7 \pm 3.6$ & $148.6 \pm 39.3$ & $707.0 \pm 21.7$ & $144.5 \pm 20.5$ \\
\hline \multirow[t]{2}{*}{ North field } & 0 to 15 & $1.3 \pm 0.0$ & $7.4 \pm 0.1$ & $120.2 \pm 7.9$ & $2.5 \pm 0.1$ & $22.4 \pm 1.0$ & $31.4 \pm 1.2$ & $119.0 \pm 31.8$ & $726.3 \pm 23.5$ & $154.7 \pm 16.6$ \\
\hline & 15 to 30 & $1.4 \pm 0.0$ & $7.2 \pm 0.1$ & $123.4 \pm 8.3$ & $2.6 \pm 0.1$ & $20.2 \pm 0.6$ & $28.9 \pm 2.3$ & $92.3 \pm 29.6$ & $741.6 \pm 31.5$ & $166.1 \pm 17.8$ \\
\hline \multirow[t]{2}{*}{ Ditches } & 0 to 15 & $1.3 \pm 0.0$ & $7.3 \pm 0.1$ & $133.7 \pm 10.5$ & $2.5 \pm 0.2$ & $20.9 \pm 2.0$ & $44.9 \pm 6.4$ & $131.5 \pm 40.5$ & $700.1 \pm 28.1$ & $168.4 \pm 12.9$ \\
\hline & 15 to 30 & $1.5 \pm 0.1$ & $7.3 \pm 0.1$ & $130.0 \pm 16.3$ & $2.9 \pm 0.2$ & $19.3 \pm 1.6$ & $38.0 \pm 6.5$ & $200.5 \pm 70.4$ & $665.2 \pm 58.0$ & $134.3 \pm 12.9$ \\
\hline
\end{tabular}

Notes: $\mathrm{EC}=$ electrical conductivity. $\mathrm{N}=$ nitrogen. $\mathrm{C}=$ carbon.

Statistical Analysis. Concentrations and loads from water sampling were log transformed and checked for assumptions of normality with the Shapiro-Wilk test and equality of variance with the Levene test using the open source statistical package $\mathrm{R}$ version 2.11.1. (Helsel and Hirsch 1993). Means of each rainfall or irrigation event were considered replications and were compared through the entire season for each constituent. If assumptions of normality were met, a paired $t$-test was performed for either equal or unequal variances to test for treatment differences for concentration and load of each constituent for each season (Helsel and Hirsch 1993). For constituents that did not meet assumptions of normality and equality of variance, a Wilcoxon signed-rank test was used to test for treatment differences (Helsel and Hirsch 1993).

To account for the differences in relative size of the fields, ditches, and tailwater ponds and distances between plots, a mixed model analysis of variance (ANOVA) was employed that incorporated a spatial covariance structure (Casanoves et al. 2005). The ANOVA tests that were significant were followed by Tukey's Honestly Significant Post Hoc Test (Zar 1974). Briefly, the mixed linear models were run after checking assumptions using the proc mixed statement in SAS version 9.3.1 (SAS Institute, Cary, North Carolina) combined with a power correlation function ( $P O W$ model), which enables $X, Y$ global positioning system coordinates to be used as a covariate. The $P O W$ model uses a onedimensional isotropic (same in all directions) power covariance, based in this case, on geographic information system coordinates and assumes no correlation between plots and homogeneous residual variances (Self and Liang 1987; Wolfinger 1993). The power correlation model is represented as $\rho_{x}^{d x i j} \rho_{y}^{d i j}$, where $d^{x i j}$ and $d^{r i j}$ are the distances between plot $i$ and plot $j$ in the $x$ and $y$ directions and $\rho_{x}$ and $\rho_{y}$ are the unknown correlation parameters in the $x$ and $y$ directions (Casanoves et al. 2005). The degrees of freedom were adjusted as suggested by Kenward and Roger (1997). This methodology has been utilized and tested against other spatial and nonspatial models in agricultural systems and has been shown to be an effective means of dealing with spatial covariance (Bajwa and Mozaffari 2007; Bajwa and Vories 2007; Casanoves et al. 2005; Goncalves et al. 2007). The model, however, is unable to simultaneously account for repeated measurements; therefore, means were compared for each site without adjustment for variation over time.

\section{Results and Discussion}

Soil Properties. Soil properties of the four locations were similar across the farm sampling sites (table 2). All soils had a silt loam texture, total carbon (C) ranged from 19.7 to $22.4 \mathrm{Mg} \mathrm{ha}^{-1}$ (8.7 to $10.0 \mathrm{tn} \mathrm{ac}^{-1}$ ), and $\mathrm{pH}$ ranged from 7.2 to 7.4 at 0 to $15 \mathrm{~cm}$ (0 to 5.9 in) depth (table 2$)$. The consistency of soil properties between sites indicates that a similar soil type occurred across the farm. Thus soil properties likely did not confound the analysis of the environmental outcomes of the BMPs.

Runoff. Winter cover cropping improved the water quality of stormwater runoff during Rainfed Y1, but in rainfed year two (Rainfed Y2), no runoff was detected due to low rainfall. Compared to the fallow, water quality constituents in winter runoff (Rainfed Y1) were lower in cover cropped fields: 44\% lower for EC and 80\% lower for TSS (mg L ${ }^{-1}$ [ppm]) (table 3). Phosphorus as DRP (mg L ${ }^{-1}[\mathrm{ppm}]$ ), however, was $86 \%$ higher in discharge water from the covercropped field compared to the fallow. Higher concentrations of DRP may be a result of increased mobilization from the mustard cover crop. Other Brassica species have been shown to increase phosphorus availability through increased citric and malic acid in the rhizosphere (Eichler-Lobermann et al. 2008; Hoffland et al. 1992; Marschner et al. 2007).

Sediment and nutrient loads were calculated for the stormwater runoff based on mean discharge for the five winter storm events (table 4). In Rainfed Y1, total discharge loads $\left(\mathrm{kg} \mathrm{ha}^{-1}\left[\mathrm{lb} \mathrm{ac}^{-1}\right]\right)$ were lower for cover cropped than fallow fields: $83 \%$ lower for TSS, 33\% lower for $\mathrm{NH}_{4}{ }^{+}-\mathrm{N}$, and $58 \%$ for DOC. Despite the large quantity of $\mathrm{C}$ in the cover crop biomass, there was no increase in DOC in runoff in either winter storm events or in the subsequent irrigation. Low DOC in runoff following the cover crop indicates gradual decomposition and possibly leaching losses.

During Irrigated Y1, a total of $944 \mathrm{~mm}$ (37.2 in) of water (figure 2) was applied on the entire farm in 10 events, 35\% of which discharged into the sediment trap (tomatoes discharge) (table 4). In Irrigated Y2, a mean total of $799 \mathrm{~mm}$ (31.5 in) of water was applied (figure 2) to the two North Field sections in 9 events, $25 \%$ of which discharged from the field section that had a prior mustard cover crop during the winter (tomatoes/ mustard) and $42 \%$ discharging from the field section that had been fallow (tomatoes/fallow). Mean irrigation discharge rates for the tomatoes/mustard and tomatoes/fallow rotations were not statistically different. Nor were there any differences in the concentrations or loads of measured constituents, except for $\mathrm{pH}$, which was significantly higher in the discharge from the tomatoes/mustard field during the summer season. 
Table 3

Mean concentration and standard errors of constituents analyzed from influent and discharge effluent from entire fields and paired sections of the North Field ( $\mathrm{F}=$ fallow and $\mathrm{M}=$ mustard cover crop) during the two-year study by season. Means are given for the total number $(n)$ of either irrigation or rainfall events. Discharge was not detected (ND) during the rainfed season in the second year due to unusually low precipitation. Measured constituents are $\mathrm{pH}$, electrical conductivity (EC), total suspended solids (TSS), volatile suspended solids (VSS), nitrate (NO ${ }_{3}^{-}-\mathrm{N}$ ), ammonium $\left(\mathrm{NH}_{4}^{+}-\mathrm{N}\right)$, dissolved reactive phosphorus (DRP), and dissolved organic carbon (DOC).

\begin{tabular}{|c|c|c|c|c|c|c|c|c|c|c|}
\hline Season & Treatment & $n$ & pH & $\begin{array}{l}E C \\
\left(\mu \mathrm{sm}^{-1}\right)\end{array}$ & $\begin{array}{l}\text { TSS } \\
\left(\mathrm{g} \mathrm{L}^{-1}\right)\end{array}$ & $\begin{array}{l}\text { VSS } \\
\left(\mathrm{g} \mathrm{L}^{-1}\right)\end{array}$ & $\begin{array}{l}\mathrm{NO}_{3}^{-}-\mathrm{N} \\
\left(\mathrm{mg} \mathrm{L}^{-1}\right)\end{array}$ & $\begin{array}{l}\mathrm{NH}_{4}^{+}-\mathrm{N} \\
\left(\mathrm{mg} \mathrm{L}^{-1}\right)\end{array}$ & $\begin{array}{l}\text { DRP } \\
\left(\mathrm{mg} \mathrm{L}^{-1}\right)\end{array}$ & $\begin{array}{l}\text { DOC } \\
\left(\mathrm{mg} \mathrm{L}^{-1}\right)\end{array}$ \\
\hline rigated Y1 & rigation influent & 10 & .1 & $5.9 \pm 46.2$ & $04 \pm 0.01$ & $15 \pm 0.00$ & \pm 0.3 & .0 & .0 & \pm 0.5 \\
\hline South Field) & Tomatoes discharge & 10 & $7.7 \pm 0.1$ & $834.6 \pm 33.8$ & $7.27 \pm 1.03$ & $0.254 \pm 0.05$ & $1.6 \pm 0.2$ & $0.1 \pm 0.0$ & $0.5 \pm 0.1$ & $3.0 \pm 0.4$ \\
\hline Rainfed Y1 & Fallow storm discharge & 5 & $6.7 \pm 0.0$ & $115.1 \pm 33.6$ ** & $0.07 \pm 0.01 *$ & $0.002 \pm 0.00$ & $0.1 \pm 0.0$ & $0.1 \pm 0.0$ & $0.2 \pm 0.0 \dagger$ & $7.4 \pm 0.0$ \\
\hline North Field) & Mustard storm discharge & 5 & $6.7 \pm 0.1$ & $64.5 \pm 16.7^{* *}$ & $0.01 \pm 0.00 *$ & $0.006 \pm 0.00$ & $0.1 \pm 0.0$ & $0.1 \pm 0.0$ & $0.4 \pm 0.1 †$ & $5.8 \pm 0.1$ \\
\hline Irrigated Y2 & Irrigation influent & 9 & $7.9 \pm 0.1$ & $600.0 \pm 18.2$ & $0.02 \pm 0.01$ & $0.017 \pm 0.00$ & $1.8 \pm 0.3$ & $0.1 \pm 0.0$ & $0.0 \pm 0.0$ & $1.9 \pm 0.4$ \\
\hline \multirow[t]{2}{*}{ (North Field) } & Tomatoes (F) discharge & 9 & $8.1 \pm 0.1 *$ & $644.0 \pm 22.7$ & $10.90 \pm 3.85$ & $0.259 \pm 0.09$ & $2.2 \pm 0.2$ & $0.2 \pm 0.1$ & $0.3 \pm 0.0$ & $3.9 \pm 0.9$ \\
\hline & Tomatoes (M) discharge & 9 & $8.3 \pm 0.0 *$ & $611.4 \pm 29.8$ & $3.99 \pm 0.93$ & $0.271 \pm 0.15$ & $1.6 \pm 0.3$ & $0.1 \pm 0.0$ & $0.3 \pm 0.0$ & $3.3 \pm 0.4$ \\
\hline Rainfed Y2 & Oats discharge & 0 & ND & ND & ND & ND & ND & ND & ND & ND \\
\hline (South/North) & Fallow discharge & 0 & ND & ND & ND & ND & ND & ND & ND & ND \\
\hline
\end{tabular}

Note: Significant difference were calculated using a paired $t$-test.

† Wilcoxon signed ranked test $p<0.05$.

$* p<0.05 * * p<0.01$

\section{Table 4}

Loads of constituents analyzed from the paired tomato fields ( $F=$ fallow and $M=$ mustard cover crop), oat field, and tailwater pond during the twoyear study by season. Loads are calculated from mean concentrations weighted by flow rates divided by the area from which the water discharged. Mean loads and standard errors are given as an event mean, where $n$ is the total number of either irrigation or rainfall events. Discharge was not detected (ND) during the rainfed season in the second year (Rainfed $Y_{2}$ ) due to unusually low precipitation. Measured constituents are total suspended solids (TSS), volatile suspended solids (VSS), nitrate $\left(\mathrm{NO}_{3}^{-}-\mathrm{N}\right)$, ammonium $\left(\mathrm{NH}_{4}^{+}-\mathrm{N}\right)$, dissolved reactive phosphorus (DRP), and dissolved organic carbon (DOC).

\begin{tabular}{|c|c|c|c|c|c|c|c|c|}
\hline Treatment & $n$ & $\begin{array}{l}\text { Volume } \\
(\mathrm{mm} \\
\left.\text { event }^{-1}\right)\end{array}$ & $\begin{array}{l}\text { TSS } \\
\text { (kg ha-1 }^{-1} \\
\left.\text { event }^{-1}\right)\end{array}$ & $\begin{array}{l}\text { VSS } \\
\text { (kg ha-1 }^{-1} \\
\left.\text { event }^{-1}\right)\end{array}$ & $\begin{array}{l}\mathrm{NO}_{3}^{-}-\mathrm{N} \\
\left(\mathrm{kg} \mathrm{ha}^{-1}\right. \\
\left.\text { event }^{-1}\right)\end{array}$ & $\begin{array}{l}\mathrm{NH}_{4}^{+}-\mathrm{N} \\
\left(\mathrm{g} \mathrm{ha}^{-1}\right. \\
\text { event }^{-1} \text { ) }\end{array}$ & $\begin{array}{l}\text { DRP } \\
\text { (g ha }^{-1} \\
\text { event }^{-1} \text { ) }\end{array}$ & $\begin{array}{l}\text { DOC } \\
\text { (kg ha-1 }^{-1} \\
\left.\text { event }^{-1}\right)\end{array}$ \\
\hline \multicolumn{9}{|l|}{ Irrigated Y1 (South Field) } \\
\hline Irrigation influent & 10 & $94.4 \pm 15.7$ & $408.4 \pm 161.3$ & $13.9 \pm 3.0$ & $1.7 \pm 0.4$ & $92.8 \pm 37.0$ & $22.4 \pm 6.2$ & $1.9 \pm 0.7$ \\
\hline Tomatoes discharge & 10 & $33.2 \pm 6.3$ & $2,384.6 \pm 81.0$ & $81.5 \pm 17.4$ & $0.6 \pm 0.2$ & $28.0 \pm 14.4$ & $70.0 \pm 20.0$ & $0.9 \pm 0.2$ \\
\hline \multicolumn{9}{|l|}{ Rainfed Y1 (North Field) } \\
\hline Fallow discharge & 5 & $9.6 \pm 3.3$ & $5.0 \pm 1.3 *$ & $0.2 \pm 0.1$ & $0.01 \pm 0.01$ & $8.3 \pm 3.2 *$ & $22.3 \pm 7.6$ & $0.7 \pm 0.2 * *$ \\
\hline Mustard discharge & 5 & $5.4 \pm 1.8$ & $0.9 \pm 0.4$ * & $0.5 \pm 0.2$ & $0.01 \pm 0.04$ & $5.6 \pm 2.7 *$ & $19.7 \pm 5.3$ & $0.3 \pm .1 * *$ \\
\hline Tailwater pond discharge & 5 & ND & ND & ND & ND & ND & ND & ND \\
\hline \multicolumn{9}{|l|}{ Irrigated Y2 (North Field) } \\
\hline Irrigation influent & 9 & $88.8 \pm 22.0$ & $14.4 \pm 7.9$ & $19.0 \pm 9.0$ & $1.8 \pm 0.5$ & $35.2 \pm 14.6$ & $35.4 \pm 14.9$ & $1.5 \pm 0.4$ \\
\hline Tomatoes (F) discharge & 9 & $37.9 \pm 9.4$ & $2,440.5 \pm 849.2$ & $93.6 \pm 36.8$ & $0.9 \pm 0.3$ & $22.6 \pm 8.0$ & $118.4 \pm 42.0$ & $1.0 \pm 0.2$ \\
\hline Tomatoes (M) discharge & 9 & $23.1 \pm 3.1$ & $902.3 \pm 211.1$ & $68.1 \pm 39.1$ & $0.4 \pm 0.1$ & $16.3 \pm 5.3$ & $60.8 \pm 10.5$ & $0.7 \pm 0.1$ \\
\hline Tailwater pond influent & 9 & $32.3 \pm 9.7$ & $1,046.1 \pm 443.2 * *$ & $51.8 \pm 23.1 * *$ & $0.6 \pm 0.3$ & $21.1 \pm 9.0$ & $134.4 \pm 49.6$ & $1.0 \pm 0.3$ \\
\hline Tailwater pond discharge & 9 & $32.3 \pm 6.7$ & $30.7 \pm 11.3 * *$ & $4.4 \pm 2.3 * *$ & $0.7 \pm 0.2$ & $50.9 \pm 30.8$ & $117.3 \pm 32.2$ & $1.4 \pm 0.4$ \\
\hline \multicolumn{9}{|c|}{ Rainfed Y2 (South/North Field) } \\
\hline Oats discharge & 0 & ND & ND & ND & ND & ND & ND & ND \\
\hline Fallow discharge & 0 & ND & ND & ND & ND & ND & ND & ND \\
\hline Tailwater pond discharge & 0 & ND & ND & ND & ND & ND & ND & ND \\
\hline
\end{tabular}

Note: Significant difference were calculated using a paired $t$-test.

$* p<0.05 * * p<0.001$ 


\section{Figure 3}

A sediment trap was monitored in 2005 (Irrigated $Y_{1}$ ) and a tailwater pond was monitored in 2006 (Irrigated Y2) for influent (discharge from the agricultural fields) and effluent (water leaving ponds) concentrations: ( $a$ and $b$ ) pH, ( $c$ and d) total suspended solids (TSS), (e and f) volatile suspended solids (VSS), ( $g$ and $h$ ) nitrate $\left(\mathrm{NO}_{3}^{-}-\mathrm{N}\right)$, and (i and $j$ ) dissolved organic carbon (DOC). In 2005, only the sediment trap was sampled, as discharge from the South Field tailwater pond was inaccessible due to its transfer through a subsurface pump to the top of the field. Means and standard errors of constituents with significant differences (paired $t$-test) are shown $\left({ }^{\star} p<0.01,{ }^{\star \star} p<0.001\right)$.

(a)

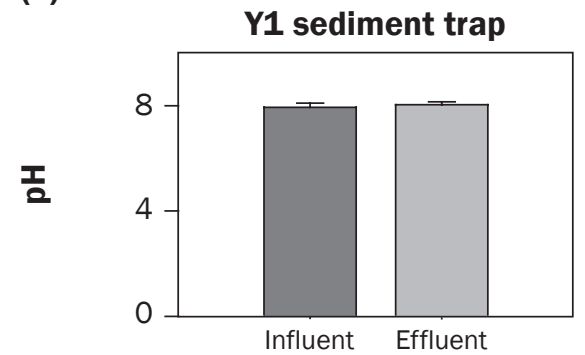

(c)

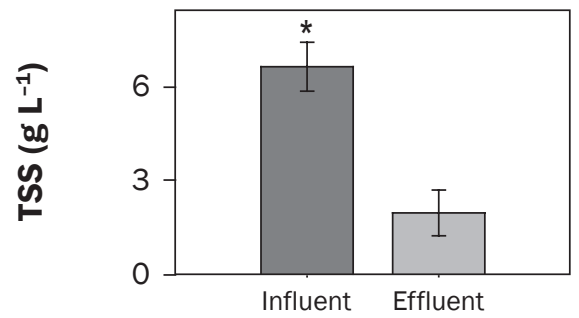

(e)

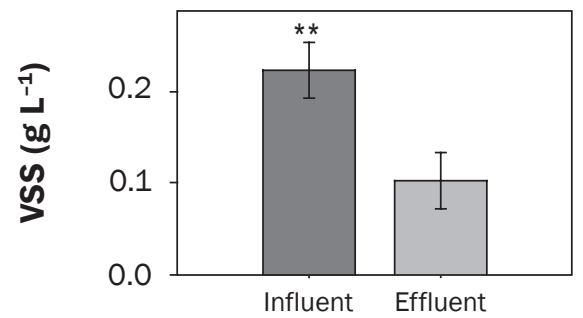

(g)

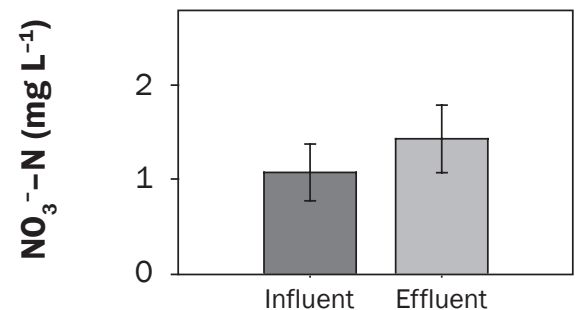

(i)

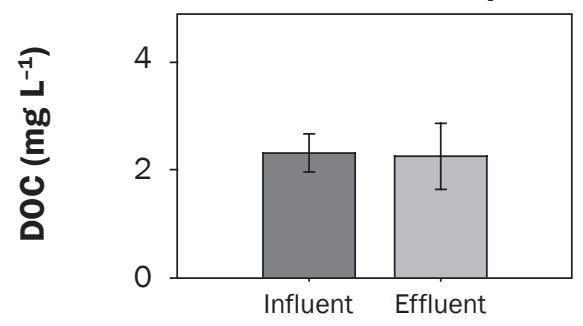

(b)

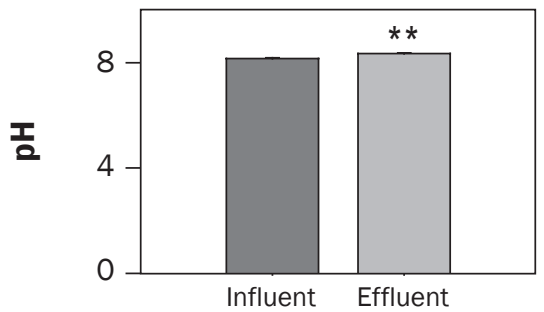

(d)

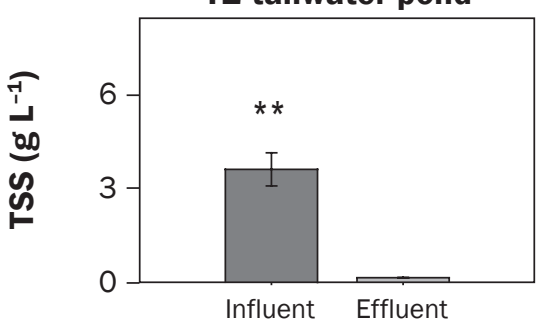

(f)

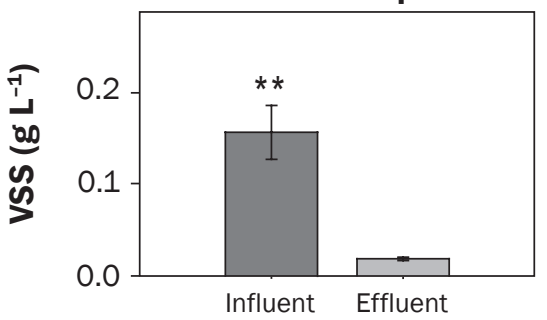

(h)

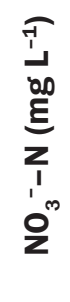

(i)

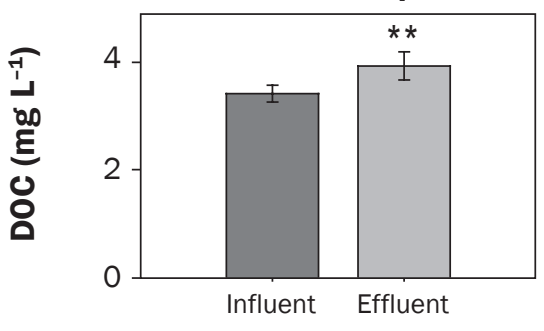

Sediment concentrations (figure 3) and loads (table 4) in the irrigation water discharging from the fields were effectively reduced by the sediment trap in irrigated $\mathrm{Y} 1$ and tailwater pond in irrigated Y2. Removal efficiencies by just the sediment trap for TSS and volatile suspended solids (VSS) on the South Field in Irrigated Y1 were 71\% and $54 \%$, respectively. Even greater reductions resulted from the tailwater pond in the North Field in Irrigated Y2, 97\% and 89\%, respectively. The total outflow (tailwater pond discharge table 4) load of TSS $\left(\mathrm{kg} \mathrm{ha}^{-1}\right.$ $\left[\mathrm{lb} \mathrm{ac}{ }^{-1}\right]$ ) was on average 35 -fold lower than inflow loads (tailwater pond influent table 4) for the nine irrigation events, a reduction for the entire season of $9.4 \mathrm{Mg} \mathrm{ha} \mathrm{M}^{-1}\left(4.1 \mathrm{tn} \mathrm{ac}^{-1}\right)$. Loads forVSS were on average 12 -fold lower than the influent (i.e., a total of $431 \mathrm{~kg} \mathrm{ha}^{-1}$ $\left[384 \mathrm{lb} \mathrm{ac}^{-1}\right]$ difference for the season).

These sediment losses via runoff were relatively high on this farm even though the amount of irrigation discharge was not. Irrigation runoff was only, on average, $34 \%$ of the applied irrigation. This was considerably lower than found in a comprehensive study of 49 furrow-irrigated farms on silt loam soils in Idaho, where discharge ranged from $43 \%$ to $53 \%$ of the total applied irrigation (Berg and Carter 1980). Although the Idaho farms were on similar slopes ( $1 \%$ to $2 \%$ ), sediment losses averaged only $5 \mathrm{Mg} \mathrm{ha}^{-1}$ season $^{-1}\left(2.2 \mathrm{tn} \mathrm{ac}^{-1}\right.$ season $\left.^{-1}\right)$, more than four times lower than observed here $\left(24 \mathrm{Mg} \mathrm{ha}^{-1}\right.$ $\left[10.7 \mathrm{tn} \mathrm{ac}^{-1}\right]$ in the first irrigation seasons). In the Idaho study, losses increased to $37 \mathrm{Mg}$ $\mathrm{ha}^{-1}\left(16.5 \mathrm{tn} \mathrm{ac}^{-1}\right)$ on slopes of $2.5 \%$ and up to $141 \mathrm{Mg} \mathrm{ha}^{-1}\left(62.8 \mathrm{tn} \mathrm{ac}^{-1}\right)$ on $4 \%$ slopes. Differences in tillage practices, soil type, the amount of surface residue, or higher irrigation inflow rates could explain the disparity in sediment losses between these studies. Much greater inflow rates, for example, were likely required to move water down the long furrow lengths (390 to $790 \mathrm{~m} \mathrm{[1,280} \mathrm{to} \mathrm{2,592}$ $\mathrm{ft}]$ ) of this farm compared to the shorter furrow lengths 132 to $313 \mathrm{~m}$ (433 to 1,026 ft) of the farms observed in the Idaho study.

Given the substantial loads due to the irrigation practices on this farm, large quantities of sediment would have been lost to the neighboring waterways despite the use of winter cover crops. Sediment loads in irrigation runoff were orders of magnitude higher than those of winter runoff. These results suggest that a tailwater pond would be a critical BMP addition to protect water quality. 
The tailwater pond alone, however, did not completely prevent nutrient runoff into the nearby waterways. Comparing the water quality indicators in irrigation discharged from the field to water exiting the tailwater pond, we observed no differences in EC, $\mathrm{NH}_{4}{ }^{+}-\mathrm{N}$, or DRP. In fact, $\mathrm{NO}_{3}{ }^{-}-\mathrm{N}$ and DOC concentrations actually increased by $40 \%$ and $20 \%$, respectively. This increase in $\mathrm{NO}_{3}{ }^{-}-\mathrm{N}$ is somewhat surprising given that $\mathrm{N}$ removal rates from polluted water are thought, in principle, to be proportional to concentration (Kadlec and Knight 1996). It is possible that this might be a result of mineralization and nitrification of organic $\mathrm{N}$ deposited in the pond, given the low concentrations of $\mathrm{NO}_{3}^{-}-\mathrm{N}$ in the irrigation runoff. Summer $\mathrm{NO}_{3}^{-}-\mathrm{N}$ losses via runoff were only 8.1 and $3.3 \mathrm{~kg} \mathrm{ha}^{-1} \mathrm{y}^{-1}$ (7.2 and $2.9 \mathrm{lb} \mathrm{ac}^{-1} \mathrm{yr}^{-1}$ ) for tomatoes grown following winter fallow and mustard cover crops, respectively, compared to, for example, a heavily manured grazed dairy pasture with annual losses of $92 \mathrm{~kg}$ $\mathrm{NO}_{3}^{-}-\mathrm{N} \mathrm{ha}^{-1}$ (81.9 $\mathrm{lb} \mathrm{NO}_{3}^{-}-\mathrm{N} \mathrm{ac}^{-1}$ ) (Tanner et al. 2005). Overall $\mathrm{NO}_{3}^{-}-\mathrm{N}$ concentrations in runoff were far lower $\left(<2.2 \mathrm{mg} \mathrm{NO}_{3}^{-}-\mathrm{N}\right.$ $\left.\mathrm{L}^{-1}\left[\mathrm{ppm} \mathrm{NO}_{3}^{-}-\mathrm{N}\right]\right)$ than the World Health Organization drinking water standard of 10 mg $\mathrm{NO}_{3}^{-}-\mathrm{N} \mathrm{L}^{-1}$ (ppm $\mathrm{NO}_{3}^{-}-\mathrm{N}$ ) (Yamamura et al. 2004). Removal rates for $\mathrm{NO}_{3}^{-} \mathrm{N}$ in constructed wetlands can be as high as $44 \%$, but these rates have been associated with much higher concentrations in effluent from dairy pastures (Tanner et al. 2005). The design of the tailwater pond (Kadlec 2005) and its effects on denitrification, sedimentation (Saunders and Kalff 2001), and hydraulic efficiency, may have limited the potential for microbial and plant $\mathrm{N}$ immobilization, due to short residence times in these ponds and their small sizes $(0.2 \%$ of the field's watershed area). Hydraulic residence time, the average time that water remains in the pond, expressed as mean volume divided by mean outflow rate in the tailwater pond was less than two days, whereas recommended hydraulic residence times are as long as 12 days for treatment wetlands (Davis 1994). Submergent and emergent vegetation can also contribute to increased removal rates of some constituents in other types of ponds (Kadlec 2005), but the ruderal plant species along the bottom and the edge of these tailwater ponds were not adapted to long-term inundation.

Concentrations of DRP in the effluent were also not reduced by detention in the tailwater pond. In tailwater ponds, phospho- rus that is sorbed to crystalline and poorly crystalline iron hydroxides may be released at low redox potentials (Bjorneberg et al. 2002). In fact, Tanner et al. (2005) found that DRP increased by $70 \%$ after flowing through a constructed treatment pond. Although we did not measure total phosphorus, if we assume that eroded sediments contain approximately $0.1 \%$ total phosphorus (Bjorneberg et al. 2002), the tailwater pond could have trapped as much as $24 \mathrm{~kg}$ phosphorus ha $\mathrm{ha}^{-1}$ (21.4 $\mathrm{lb}$ phosphorus $\mathrm{ac}^{-1}$ ) during a single irrigation season given the mass of TSS that was retained.

Without a tailwater return system, improving the effectiveness of a tailwater pond through increased detention time or greater plant cover may require tough decisions as to which pollutants should be managed. The short detention time may not have been long enough to adequately decrease $\mathrm{NO}_{3}^{-}-\mathrm{N}$ and DRP, but it appears to have been sufficient for microbes to break down and dissolve particulate $\mathrm{C}$ into solution, thereby increasing the DOC concentration in the effluent. Increasing the retention times by expanding the size of the tailwater pond or slowing the flow through baffles may reduce eutrophication. But it may not decrease DOC, which can cause toxic byproducts during the municipal drinking water treatment process used in this region (Fujii et al. 1998). Additionally increasing the size of the pond requires added investment and reduces the area of tomato production.

Leaching of Nitrate. Leaching of $\mathrm{NO}_{3}^{-}-\mathrm{N}$, as measured by the anion exchange resin bags was similar (approximately $24.7 \mathrm{~kg}$ $\mathrm{NO}_{3}^{-}-\mathrm{N} \mathrm{ha}^{-1}$ [22 $\left.\mathrm{lb} \mathrm{NO}_{3}^{-}-\mathrm{N} \mathrm{ac}^{-1}\right]$ ) for the fields, ditches, and tailwater ponds in Rainfed Y1 (figure 4). There were no differences observed between the winter cover crop and fallow fields. Interestingly, in the Rainfed Y2 season, despite the low rainfall, $\mathrm{NO}_{3}^{-}-\mathrm{N}$ in the resin bags was two-fold higher in the tailwater pond and three-fold higher in ditches than in the fields. The higher $\mathrm{NO}_{3}^{-}-\mathrm{N}$ leaching during the drier Rainfed Y2 season in these areas that accumulate water was likely due to slightly higher moisture content and enhanced nitrification compared to the fields, particularly during the warm fall and spring (Burger and Jackson 2003; Stark and Firestone 1995). In addition, there was little to no nutrient removal via runoff, and absence of anaerobic conditions would have limited denitrification, causing inorganic $\mathrm{N}$ to accumulate in the surface soil.

Significant differences in $\mathrm{NO}_{3}{ }^{-} \mathrm{N}$ concentrations in lysimeters varied among fields, ditches, and the tailwater pond by season and by depth (table 5), but differences in cumulative losses were found only in Rainfed Y1 (figure 4). Estimated DP, used to calculate cumulative leaching losses, was 157 $\mathrm{mm}$ (6.2 in) during the Irrigated Y1 season with tomatoes. During the Rainfed Y1 season, DP ranged from 92 to $112 \mathrm{~mm}(3.62$ to $4.41 \mathrm{in})$. In the Irrigated Y2 season, DP ranged from $169 \mathrm{~mm}$ (6.7 in) for the tomatoes/fallow compared to $326 \mathrm{~mm}$ (12.8 in) for the tomatoes/mustard treatment. No DP could be estimated for the Rainfed Y2 season due to low rainfall. Estimates of $\mathrm{NO}_{3}^{-}-\mathrm{N}$ leaching using lysimeter concentrations and the water balance method were lower than those obtained using the anion exchange resin bags, especially during the Irrigated Y1 season (figure 4). Others however, have shown the opposite, with higher values in lysimeters than resin bags (Wyland et al. 1996). Accurately assessing soil solute chemistry is often dependent on matching the methodology with the soil type (Siemens and Kaupenjohann 2004). Here, the collection schedule did not always match with the irrigation schedule, and some wet-dry cycles were inadvertently missed, probably underestimating cumulative losses using the lysimeter method. Furthermore, cumulative losses calculated based on estimates of water percolation are subject to error if the return to field capacity is not correctly identified (Webster et al. 1993).

Leaching of Other Constituents. In soil solution collected in the lysimeters, $\mathrm{pH}$ and EC were very similar and consistent among treatments throughout the two years. The only difference was higher EC values in soil solution for lysimeters at $30 \mathrm{~cm}$ (12 in) in the tomato field and ditches, compared to the tailwater pond in the Irrigated $\mathrm{Y} 1$ season (table 5).

Leachate $\mathrm{NH}_{4}^{+}-\mathrm{N}$ and calculated $\mathrm{NH}_{4}{ }^{+}-\mathrm{N}$ load were low overall (data not shown). Seasonal cumulative DRP leached below the $60 \mathrm{~cm}$ (23.6 in) depth also showed the same pattern. Concentrations of DOC tended to be lowest in the lysimeters in the tailwater pond (table 5). Results indicate that cover cropping may be a source of DOC during the winter rains. Dissolved organic C concentrations in RainfedY1 were clearly 
Table 5

Mean lysimeter concentrations and standard errors by season and depth during the two-year study for the paired tomato fields ( $F=$ fallow and $M=$ mustard cover crop). Lysimeters were sampled weekly during irrigation and precipitation periods.

\begin{tabular}{|c|c|c|c|c|c|c|c|}
\hline Season & Site & $\begin{array}{l}\text { Depth } \\
\text { (cm) }\end{array}$ & pH & $\begin{array}{l}\mathrm{EC} \\
\left(\mu \mathrm{cm}^{-1}\right)\end{array}$ & $\begin{array}{l}\mathrm{NO}_{3}^{-}-\mathrm{N} \\
\left(\mathrm{mg} \mathrm{L}^{-1}\right)\end{array}$ & $\begin{array}{l}\text { DRP } \\
\left(\mathrm{mg} \mathrm{L}^{-1}\right)\end{array}$ & $\begin{array}{l}\text { DOC } \\
\left(\mathrm{mg} \mathrm{L}^{-1}\right)\end{array}$ \\
\hline \multirow[t]{5}{*}{ Irrigated Y1 } & Oats* & & ND & ND & ND & ND & ND \\
\hline & Tomatoes & 30 & $7.4 \pm 0.1$ & $904.6 \pm 33.1 \mathrm{~A}$ & $5.0 \pm 1.2 \mathrm{~A}$ & $0.1 \pm 0.0$ & $5.2 \pm 0.7 \mathrm{AB}$ \\
\hline & & 60 & $7.5 \pm 0.0$ & $894.3 \pm 44.7$ & $3.4 \pm 1.0$ & $0.0 \pm 0.0$ & $4.9 \pm 0.9 b$ \\
\hline & Ditches & 30 & $7.4 \pm 0.0$ & $1,069.0 \pm 14.0 \mathrm{~A}$ & $1.1 \pm 0.4 \mathrm{~B}$ & $0.7 \pm 0.5$ & $13.7 \pm 8.6 \mathrm{~A}$ \\
\hline & & 60 & $7.3 \pm 0.2$ & $1,039.7 \pm 216.9$ & $2.6 \pm 1.7$ & $0.1 \pm 0.1$ & $22.5 \pm 7.1 \mathrm{a}$ \\
\hline \multirow[t]{6}{*}{ Rainfed Y1 } & Oats & 30 & $7.0 \pm 0.1$ & $905.8 \pm 172.8$ & $6.1 \pm 1.9 \mathrm{AB}$ & $0.1 \pm 0.1$ & $13.3 \pm 2.5 \mathrm{~B}$ \\
\hline & & 60 & $7.1 \pm 0.0$ & $890.0 \pm 103.8$ & $3.9 \pm 1.6$ & $0.0 \pm 0.0$ & $8.8 \pm 1.6$ \\
\hline & Fallow & 30 & $7.2 \pm 0.0$ & $788.4 \pm 145.1$ & $1.1 \pm 0.5 \mathrm{~B}$ & $0.1 \pm 0.1$ & $30.2 \pm 10.8 \mathrm{AB}$ \\
\hline & & 60 & $7.3 \pm 0.1$ & $1,026.9 \pm 116.4$ & $8.9 \pm 3.4$ & $0.0 \pm 0.0$ & $13.0 \pm 3.2$ \\
\hline & Mustard & 30 & $7.0 \pm 0.1$ & $1,226.3 \pm 258.7$ & $3.2 \pm 1.8 \mathrm{AB}$ & $0.2 \pm 0.1$ & $70.1 \pm 17.5 \mathrm{~A}$ \\
\hline & Tailwater pond $\dagger$ & & ND & ND & ND & ND & ND \\
\hline \multirow[t]{9}{*}{ Irrigated Y2 } & Oats* & & ND & ND & ND & ND & ND \\
\hline & Tomatoes (F) & 30 & $7.6 \pm 0.3$ & $783.7 \pm 79.5$ & $7.2 \pm 4.1$ & $0.2 \pm 0.0$ & $13.9 \pm 1.4 \mathrm{~A}$ \\
\hline & & 60 & $7.7 \pm 0.1$ & $721.1 \pm 94.8$ & $4.0 \pm 1.0 a$ & $0.1 \pm 0.0$ & $10.1 \pm 1.3 a$ \\
\hline & Tomatoes (M) & 30 & $7.3 \pm 0.1$ & $726.7 \pm 158.4$ & $4.2 \pm 0.3$ & $0.3 \pm 0.1$ & $11.9 \pm 2.2 \mathrm{~A}$ \\
\hline & & 60 & $7.5 \pm 0.1$ & $918.1 \pm 98.4$ & $4.1 \pm 0.6 a$ & $0.1 \pm 0.0$ & $16.3 \pm 0.5 a$ \\
\hline & Ditches & 30 & $7.6 \pm 0.2$ & $789.8 \pm 71.6$ & $4.6 \pm 0.8$ & $0.2 \pm 0.1$ & $7.8 \pm 0.4 A B$ \\
\hline & & 60 & $7.7 \pm 0.2$ & $800.1 \pm 36.0$ & $3.2 \pm 0.6 a$ & $0.1 \pm 0.0$ & $13.1 \pm 1.2 \mathrm{a}$ \\
\hline & Tailwater pond & 30 & $7.5 \pm 0.1$ & $652.9 \pm 47.8$ & $1.2 \pm 0.3$ & $0.1 \pm 0.0$ & $5.4 \pm 0.7 \mathrm{~B}$ \\
\hline & & 60 & $7.6 \pm 0.1$ & $594.6 \pm 62.1$ & $0.6 \pm 0.2 b$ & $0.0 \pm 0.0$ & $5.6 \pm 1.4 b$ \\
\hline Rainfed Y2 & & 60 & $7.5 \pm 0.1$ & $585.4 \pm 31.7$ & $1.6 \pm 1.3$ & $0.0 \pm 0.0$ & $2.0 \pm 0.2$ \\
\hline
\end{tabular}

Note: Letters ( $A$ and $B$ ) indicate significant differences at the 0 to $30 \mathrm{~cm}$ depth and (a and $b)$ at the 30 to $60 \mathrm{~cm}$ depth among sites within each season using a covariance analysis of variance followed by Tukey's Honestly Significant Post Hoc Test.

* No data was collected for oats during the summer because no irrigation was applied.

$\dagger$ No data was collected for the tailwater pond due to lysimeter contamination caused by flooding.

higher in the mustard winter cover crop than for the oats and ditches $(p<0.01)$ but did not differ from the fallow. Calculated DOC leaching losses below the $60 \mathrm{~cm}$ depth for the cover crop $\left(40.7 \mathrm{~kg} \mathrm{C} \mathrm{ha}^{-1}[36.3 \mathrm{lb} \mathrm{C}\right.$ $\left.\left.\mathrm{ac}^{-1}\right]\right)$ were also higher $(p<0.001)$ than oats and ditches (17.0 and $7.627 \mathrm{~kg} \mathrm{C} \mathrm{ha}^{-1}[15.1$ and $6.79 \mathrm{lb} \mathrm{C} \mathrm{ac}^{-1}$, respectively) with the fallow field in between $\left(24.0 \mathrm{~kg} \mathrm{C} \mathrm{ha}^{-1}[21.4\right.$ lb C ac$\left.{ }^{-1}\right]$ ).

During the Irrigated $\mathrm{Y} 1$ season, lysimeter DOC concentrations in the ditches were higher than the other sites $(p<0.01)$, and loads that leached below $60 \mathrm{~cm}$ (23.6 in) were $33.8 \mathrm{~kg} \mathrm{C} \mathrm{ha}^{-1}\left(30.1 \mathrm{lb} \mathrm{C} \mathrm{ac}^{-1}\right) \mathrm{com}-$ pared to $6.9 \mathrm{~kg} \mathrm{C} \mathrm{ha}^{-1}\left(6.2 \mathrm{lb} \mathrm{C} \mathrm{ac}^{-1}\right)$ for the field. In the subsequent irrigation season (Irrigated Y2), DOC concentrations were again higher in the fields than the tailwater pond but did not otherwise differ. Dissolved organic C loads, however, were substantially higher in the tomatoes/mustard $(54.1 \mathrm{~kg} \mathrm{C}$ $\left.\mathrm{ha}^{-1}\left[48.2 \mathrm{lb} \mathrm{C} \mathrm{ac}^{-1}\right]\right)$ than in the tomatoes/ fallow $\left(14.2 \mathrm{~kg} \mathrm{C} \mathrm{ha}^{-1}\left[12.7 \mathrm{lb} \mathrm{C} \mathrm{ac}^{-1}\right]\right)$ treat- ment. When the seasons are summed, the DOC loads for the tomatoes/fallow rotation were almost as high as annual averages of DOC leachate collected in a four-year study of conventional maize in Wisconsin using equilibrium lysimeters for no-till (108.7 kg C ha $\left.{ }^{-1} \mathrm{y}^{-1}\left[96.8 \mathrm{lb} \mathrm{ac}^{-1} \mathrm{yr}^{-1}\right]\right)$ and chisel-plowed treatments $\left(125.5 \mathrm{~kg} \mathrm{C} \mathrm{ha}^{-1}\right.$ $\left.\mathrm{y}^{-1}\left[111.8 \mathrm{lb} \mathrm{ac}^{-1} \mathrm{yr}^{-1}\right]\right)$ (Brye et al. 2001).

Although it is unclear how much leached DOC actually would impact the adjacent waterways, the relative differences in esti- 


\section{Figure 4}

(a, b, c, and d) Cumulative mean $\mathrm{NO}_{3}^{-}-\mathrm{N}$ leaching by season measured by anion exchange resin bags (columns) buried at $75 \mathrm{~cm}$ and loads calculated from data from lysimeters (dots) at $60 \mathrm{~cm}$ of depth. Tailwater pond lysimeters in Rainfed $Y_{1}$ were excluded from the analysis because of flooding, indicated by ND. (e, f, g, and h) Soil NO${ }_{3}^{-}-\mathrm{N}$ concentrations taken incrementally every $15 \mathrm{~cm}$ to a depth of $75 \mathrm{~cm}(29.5$ in) at the start (white column) and at the end of the season (dark columns). Error bars represent standard errors. Letters ( $a, b$, and $c)$ indicate significant difference ( $p<0.05)$ among anion exchange resin bag data and calculated loads ( $x$ and $y$ ) using a spatial covariance analysis of variance followed by Tukey's Honestrly Significant Post Hoc Test (see table 5 for statistical analysis of lysimeter concentrations). $\mathrm{F}=$ fallow and $\mathrm{M}=$ mustard cover crop.

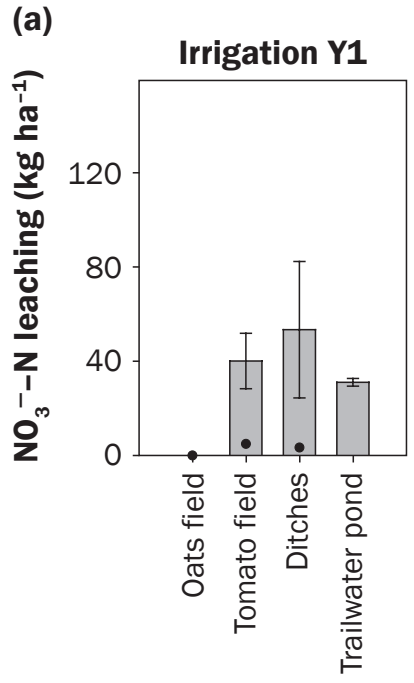

Location (b)

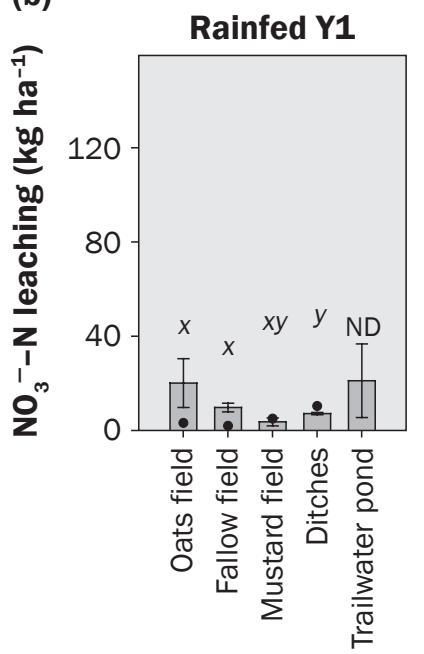

Location (c)

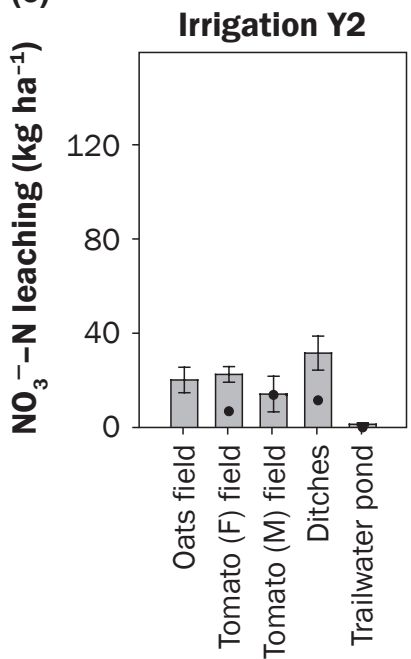

Location (d)

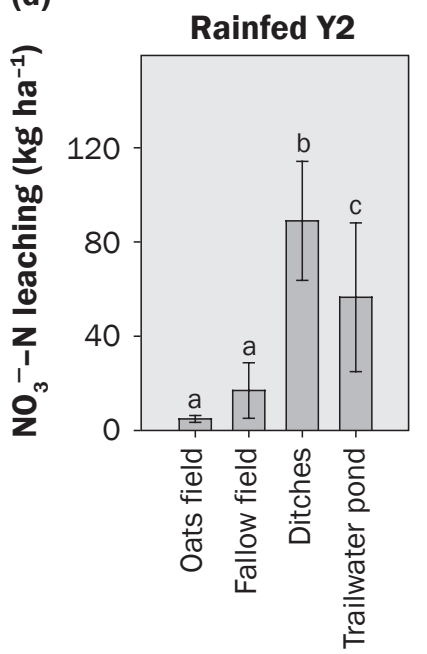

Location

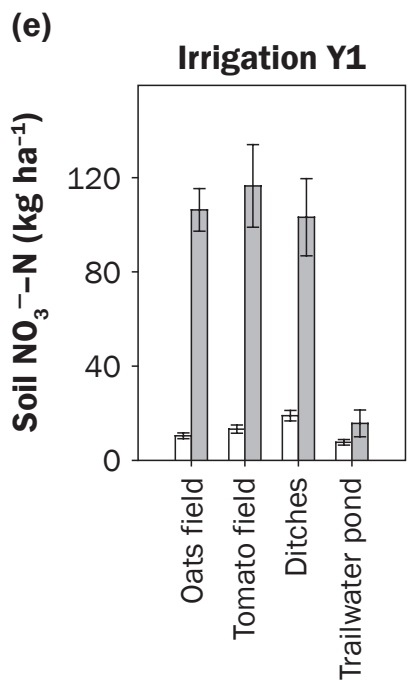

Location (f)

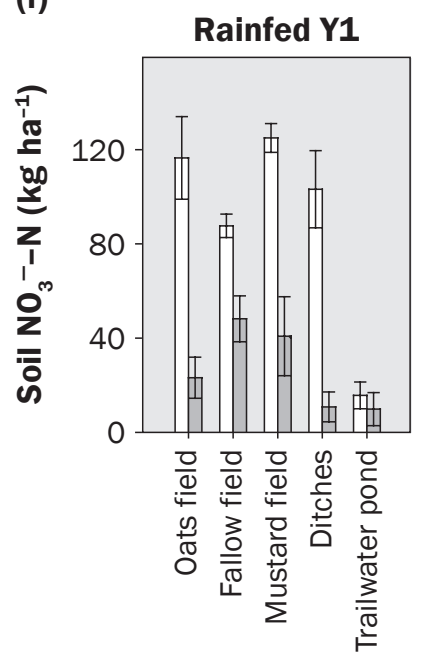

Location (g)

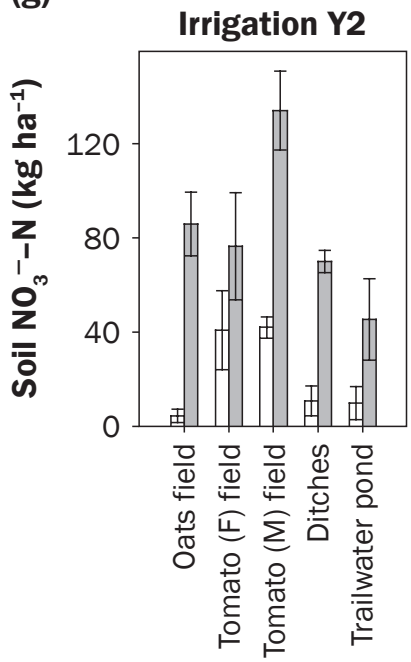

Location (h)

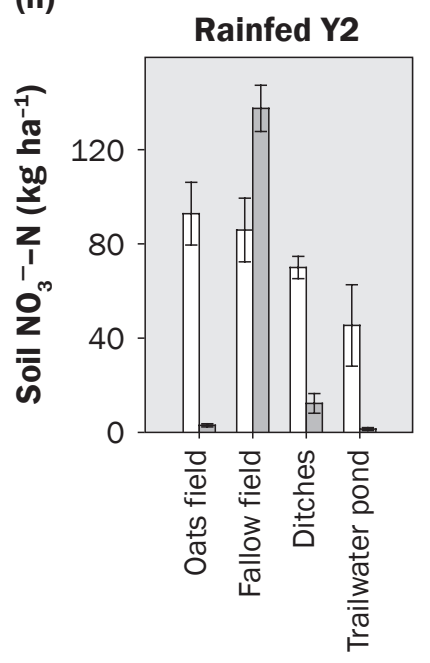

Location

Legend 
mated load indicate an important potential negative tradeoff of using cover crops and the need to manage both their decomposition and irrigation runoff carefully. Transport of DOC away from the field may be largely determined by how much irrigation water is lost as DP (Brye et al.2001). During Irrigated $\mathrm{Y} 1$, it was estimated that only $16 \%$ of the water was lost as DP. In Irrigated Y2, 15\% of the water was lost as DP in the tomato field following the winter fallow, and $27 \%$ was lost in the tomato field following the mustard cover crop. Deep percolation and associated DOC could be reduced if cover crops are managed carefully to prevent residue from blocking furrows, which causes ponding and increased infiltration, either by mowing/ incorporating earlier to increase decomposition (weather permitting) or by improved irrigation efficiency.

Nitrous Oxide-Nitrogen and Carbon Dioxide-Carbon Soil Emissions. During the irrigation seasons, mean $\mathrm{N}_{2} \mathrm{O}-\mathrm{N}$ emissions $\left(\mu \mathrm{g} \mathrm{m} \mathrm{m}^{-2} \mathrm{~h}^{-1}\right.$ ) were similar across the fields, ditches, and pond, but in the rainfed seasons, differences were significant (figure 5). The $\mathrm{N}_{2} \mathrm{O}-\mathrm{N}$ emission rates in the ditches during the Rainfed $\mathrm{Y} 1$ season were 4-, 7- and 9fold higher than oat, mustard, or fallow fields, respectively. In the Rainfed $\mathrm{Y} 2$ season, the tailwater pond had the highest $\mathrm{N}_{2} \mathrm{O}-\mathrm{N}$ emission rates, followed closely by the ditches, and both were higher than the fallow field but were not different from the oat field.

Soil $\mathrm{CO}_{2}-\mathrm{C}$ emission rates were higher in the tomato fields following a fallow, compared to ponds and ditches. Rates $\left(\mathrm{mg} \mathrm{m}^{-2}\right.$ $\mathrm{h}^{-1}$ ) from the tomato field were 2.5 times higher than in the nonirrigated oat field during Irrigated Y1 (figure 5). In Irrigated Y2, the tomato field following the winter fallow had 3.5-fold higher $\mathrm{CO}_{2}-\mathrm{C}$ emissions than the tailwater pond but was not different from the other sites. Mean $\mathrm{CO}_{2}-\mathrm{C}$ emissions were not different in Rainfed Y1. In Rainfed Y2, emissions were almost 2-fold higher in the fallow and oat fields, compared to the tailwater pond, but were no different than the ditches.

Mean seasonal $\mathrm{N}_{2} \mathrm{O}-\mathrm{N}$ emissions were always $<5 \mathrm{~g} \mathrm{ha}^{-1} \mathrm{~d}^{-1}\left(0.004 \mathrm{lb} \mathrm{ac}^{-1}\right.$ day $\left.^{-1}\right)$, much lower than many conventionally managed systems, such as a cornfield fertilized with $290 \mathrm{~kg} \mathrm{~N} \mathrm{ha}{ }^{-1}\left(259 \mathrm{lb} \mathrm{N} \mathrm{ac}^{-1}\right)$, where emissions were $52 \mathrm{~g} \mathrm{~N}_{2} \mathrm{O}-\mathrm{N} \mathrm{ha}^{-1} \mathrm{~d}^{-1}$ (0.05 $\mathrm{lb} \mathrm{N}_{2} \mathrm{O}-\mathrm{N} \mathrm{ac}^{-1}$ day $^{-1}$ ) (McSwiney and Robertson 2005). Our results were more similar to means for unfertilized corn in

\section{Table 6}

Tomato yields and weed biomass for 2005 and 2006. Mean fresh weights ( $\mathrm{fw}$ ) and standard errors for tomatoes in each field have been classified by quality ( $n=6$ in 2005 and $n=3$ in 2006). Total aboveground biomass is reported as dry weight (dw).

\begin{tabular}{|c|c|c|c|}
\hline \multirow[b]{2}{*}{$\underline{\text { Harvested material }\left(\mathrm{Mg} \mathrm{ha}^{-1}\right)}$} & \multirow[t]{2}{*}{2005} & \multicolumn{2}{|l|}{2006} \\
\hline & & Fallow & Mustard \\
\hline Weed biomass (dw) & $0.2 \pm 0.0$ & $2.2 \pm 0.9$ & $2.1 \pm 0.6$ \\
\hline Total aboveground tomato biomass (dw) & $3.5 \pm 0.5$ & $15.9 \pm 2.9$ & $11.4 \pm 3.5$ \\
\hline Split red tomatoes (fw) & $1.8 \pm 0.5$ & $6.5 \pm 3.9 b$ & $6.8 \pm 2.1 a$ \\
\hline Pink tomatoes (fw) & $3.0 \pm 0.5$ & $10.8 \pm 4.5 b$ & $13.2 \pm 3.1 a$ \\
\hline Green tomatoes ( $\mathrm{fw}$ ) & $3.1 \pm 0.7$ & $14.5 \pm 5.0$ & $22.4 \pm 3.6$ \\
\hline Sunburn tomatoes (fw) & $6.3 \pm 0.7$ & $20.4 \pm 4.1$ & $19.3 \pm 3.4$ \\
\hline Moldy or rotten tomatoes ( $\mathrm{fw}$ ) & $10.6 \pm 1.1$ & $27.3 \pm 5.0$ & $36.0 \pm 6.4$ \\
\hline Blossom end rot tomatoes (fw) & $1.7 \pm 0.4$ & $1.9 \pm 0.5$ & $4.4 \pm 1.2$ \\
\hline Insect damaged tomatoes (fw) & $1.7 \pm 0.6$ & $5.0 \pm 2.4$ & $11.4 \pm 2.7$ \\
\hline Undamaged tomatoes (fw) & $15.7 \pm 3.9$ & $67.1 \pm 5.5$ & $55.0 \pm 10.9$ \\
\hline Total fruit biomass (fw) & $46.9 \pm 6.9$ & $153.6 \pm 19.3$ & $168.5 \pm 15.3$ \\
\hline
\end{tabular}

Note: Letters indicate significant differences between the fallow and mustard rotations within each season using a covariance analysis of variance followed by Tukey's Honestly Significant Post Hoc Test.

the same study $\left(5 \mathrm{~g} \mathrm{~N}_{2} \mathrm{O}-\mathrm{N} \mathrm{ha}{ }^{-1} \mathrm{~d}^{-1}[0.004\right.$ lb $\left.\mathrm{N}_{2} \mathrm{O}-\mathrm{N} \mathrm{ac}{ }^{-1} \mathrm{day}^{-1}\right]$ ), and for a long term organic production trial in the Midwest United States $\left(3.5 \mathrm{~g} \mathrm{~N}_{2} \mathrm{O}-\mathrm{N} \mathrm{ha}^{-1} \mathrm{~d}^{-1}[0.003 \mathrm{lb}\right.$ $\mathrm{N}_{2} \mathrm{O}-\mathrm{N} \mathrm{ac}{ }^{-1}$ day $^{-1}$ ) (Robertson et al. 2000). Other organic farming systems, however, have shown much higher mean emissions (10 to $70 \mathrm{~g} \mathrm{~N}_{2} \mathrm{O}-\mathrm{N} \mathrm{ha}{ }^{-1} \mathrm{~d}^{-1}$ ) [0.009 to 0.06 lb N $\mathrm{O}_{2} \mathrm{O} \mathrm{N} \mathrm{ac}^{-1} \mathrm{day}^{-1}$ ) (Baggs et al. 2000).

Monthly sampling may have underestimated actual emissions as large spikes can occur on short time frames. For example, a large spike was observed (16 g N $\mathrm{N}_{2} \mathrm{O}-\mathrm{N}$ $\mathrm{ha}^{-1} \mathrm{~h}^{-1}$ [0.01 lb N $\left.\mathrm{N}_{2} \mathrm{O}-\mathrm{N} \mathrm{ac} \mathrm{ac}^{-1} \mathrm{hr}^{-1}\right]$ ) in the cover cropped field two days after irrigation. Irrigated vegetable production systems have high temporal and spatial variation in moisture and inorganic $\mathrm{N}$ between fields, ditches, and tailwater ponds (Sanchez-Martin et al. 2008). Thus these calculations of annual fluxes are considered estimates. These estimates indicate that while there are likely no increases in $\mathrm{CO}_{2}-\mathrm{C}$ emissions due to $\mathrm{BMP}$ implementation, there are significant increases in $\mathrm{N}_{2} \mathrm{O}-\mathrm{N}$ emissions from tailwater ponds. How much this increases the overall global warming potential of the farm is contingent upon the relative size of the pond and its associated drying and wetting soils as well as the frequency of inundation.

Tomato Yields. In the first year of the experiment, late spring rains followed by high summer temperatures (figure 2) resulted in a fungal disease outbreak (Sclerotium rolfsii [Southern Blight]). The disease reduced plant density dramatically over the season (data not shown). By harvest, nearly one-quarter of the tomato crop showed disease damage (table 6), and yields were very low. No control measures are available for this disease, even under conventional production (AVRDC-The World Vegetable Center 2010).

In the second year, there was little disease, and yields were much higher (no statistical comparison was made between years). At harvest, neither total crop yields, crop aboveground biomass, nor weed biomass differed between the prior winter fallow and mustard cover crop treatments (table 6). There were, however, more split red tomatoes and pink tomatoes following the mustard cover crop treatment. Only one-third of the tomatoes were undamaged, yet the grower harvested several of the other categories as is typical for machine-harvested processing tomatoes.

Tomato Nutrient Uptake and Yields. Tomato $\mathrm{N}$ uptake is another factor that contributes to the temporal and spatial variability of $\mathrm{N}$ dynamics. Larger $\mathrm{N}_{2} \mathrm{O}$ emissions and $\mathrm{NO}_{3}^{-}-\mathrm{N}$ leaching observed during Irrigated $\mathrm{Y} 1$ compared to Irrigated Y2 indicate that there was greater soil $\mathrm{N}$ availability in the first year with the diseased tomatos. One explanation may be that the residue from the tomatoes that grew nearly to maturity and died in the outbreak of Southern Blight underwent decomposition and $\mathrm{N}$ mineralization during the crop-growing season, increasing soil inorganic $\mathrm{N}$ concentrations. If this was the case, potentially $7.9 \mathrm{Mg}(8.6 \mathrm{tn})$ of plant material from the biomass of these dead plants (estimated by the difference between the harvested live biomass of the diseased field of the first year and the healthy 
Figure 5

Seasonal means of soil (a, b, c, and d) carbon dioxide-carbon $\left(\mathrm{CO}_{2}-\mathrm{C}\right)$ and $(\mathrm{e}, \mathrm{f}, \mathrm{g}$, and $\mathrm{h})$ nitrous oxide-nitrogen $\left(\mathrm{N}_{2} \mathrm{O}-\mathrm{N}\right)$ emissions and standard errors (bars) sampled monthly with a LiCOR 8100 and closed chambers, respectively. $F=$ fallow and $M=$ mustard cover crop.

Letters indicate significant difference $(p<0.05)$ using a spatial covariance analysis of variance followed by Tukey's Honestly Significant Post Hoc Test.

(a)

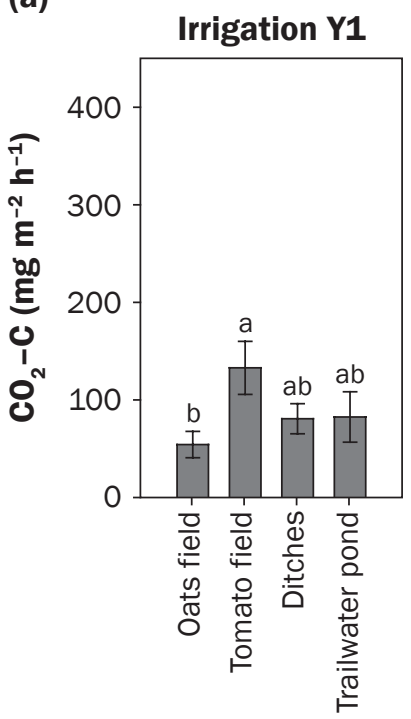

Location

(e)

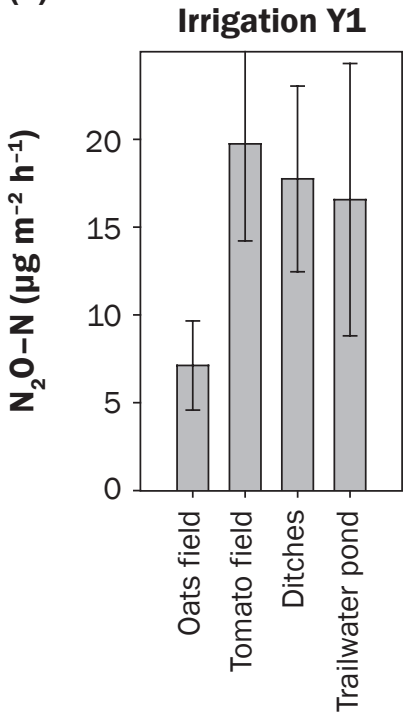

Location (b)

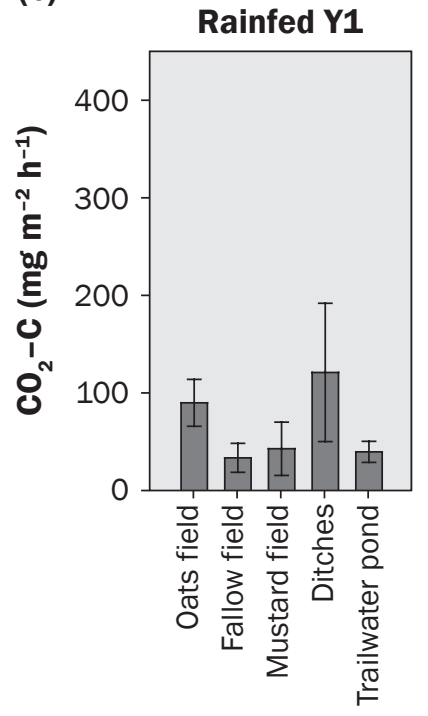

Location (c)

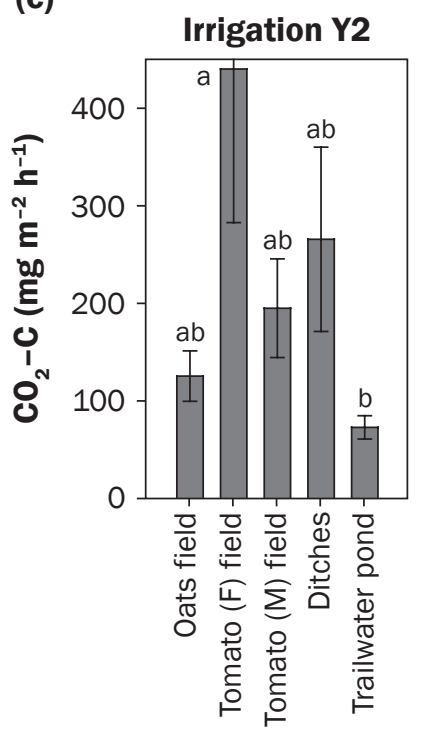

Location (d)

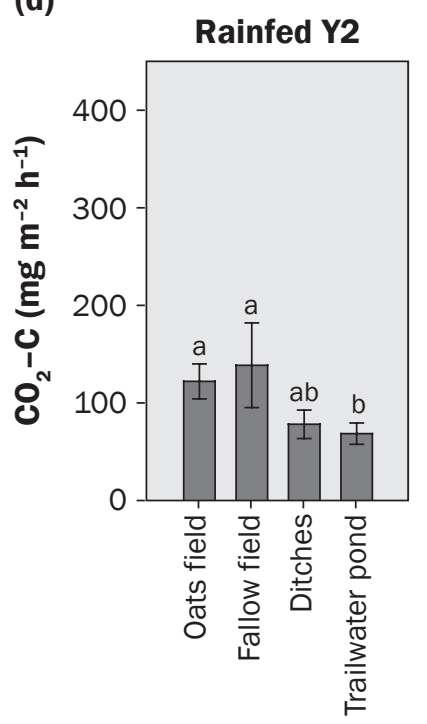

Location (f)

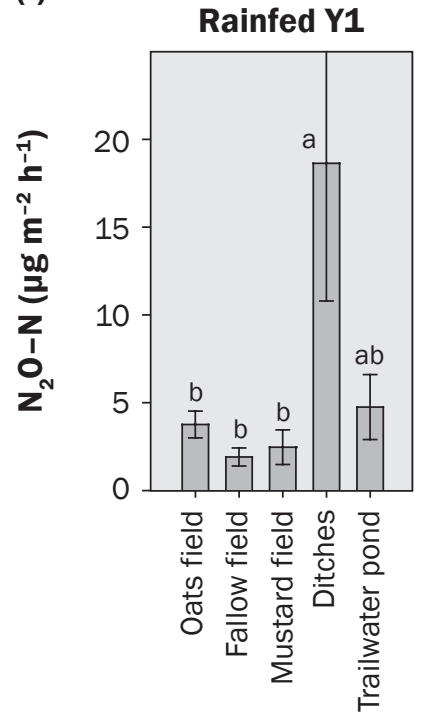

(g)

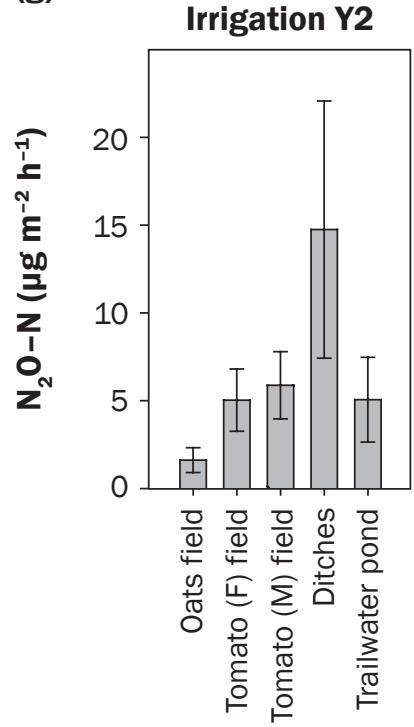

(h)

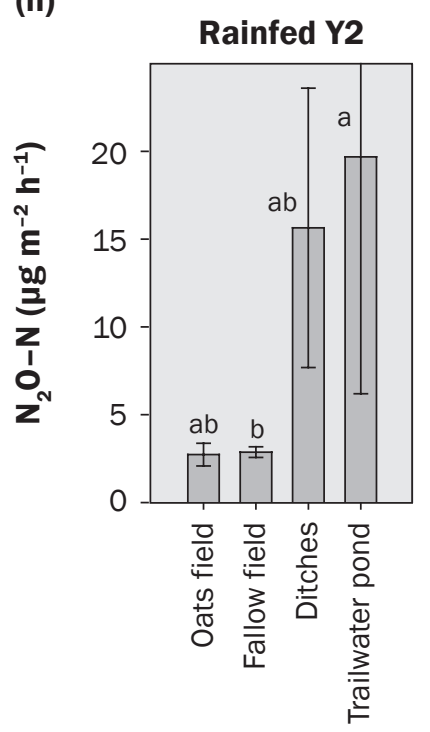

Location

Location 


\section{Table 7}

Tradeoff analysis for BMP alternatives based on the extrapolation of plot and field observations of environmental and production indicators to the entire farm area in tomato production for one year. Values for various management options are illustrated as a per hectare average annual rate with standard errors for marketable tomato yields (Yields), total suspended solids (TSS), nitrate ( $\left.\mathrm{NO}_{3}^{-}-\mathrm{N}\right)$, dissolved reactive phosphorus (DRP), dissolved organic carbon ( $\mathrm{DOC}$ ), soil nitrous oxide $\left(\mathrm{N}_{2} \mathrm{O}\right)$ emissions given in carbon dioxide equivalents $\left(\mathrm{CO}_{2}\right.$ eq), and carbon dioxide emissions ( $\left.\mathrm{CO}_{2}\right)$. Estimates were calculated for tomato production for a winter fallow only, winter cover crops only (Cover crops), winter cover crops and tailwater ponds (cover crop + tailwater pond), or winter cover crops, tailwater ponds and a tailwater return system (cover crops + tailwater pond + Return).

\begin{tabular}{|c|c|c|c|c|c|c|c|}
\hline Management options & $\begin{array}{l}\text { Yield } \\
\left(\mathrm{Mg} \mathrm{ha}^{-1} \mathrm{y}^{-1}\right) \\
\end{array}$ & $\begin{array}{l}\text { TSS } \\
\left(\mathrm{Mg} \mathrm{ha}^{-1} \mathrm{y}^{-1}\right)\end{array}$ & $\begin{array}{l}\mathrm{NO}_{3}^{-}-\mathrm{N} \\
\left(\mathrm{kg} \mathrm{ha}^{-1} \mathrm{y}^{-1}\right) \\
\end{array}$ & $\begin{array}{l}\text { DRP } \\
\left(\mathrm{kg} \mathrm{ha}^{-1} \mathrm{y}^{-1}\right) \\
\end{array}$ & $\begin{array}{l}\text { DOC } \\
\left(\mathrm{kg} \mathrm{ha}^{-1} \mathrm{y}^{-1}\right)\end{array}$ & $\begin{array}{l}\mathrm{N}_{2} \mathrm{O} \\
\left(\mathrm{CO}_{2} \text { eq kg ha-1 } \mathrm{y}^{-1}\right)\end{array}$ & $\begin{array}{l}\mathrm{CO}_{2} \\
\left(\mathrm{Mg} \mathrm{ha}^{-1} \mathrm{y}^{-1}\right)\end{array}$ \\
\hline Fallow rotation & $109.9 \pm 20.4$ & $22.0 \pm 7.6$ & $19.2 \pm 8.9$ & $1.4 \pm 0.6$ & $46.9 \pm 18.0$ & $138.6 \pm 45.7$ & $76.0 \pm 27.7$ \\
\hline Cover crop & $105.6 \pm 22.2$ & $8.1 \pm 1.9$ & $19.4 \pm 4.4$ & $1.3 \pm 0.2$ & $76.0 \pm 13.4$ & $166.4 \pm 57.8$ & $38.2 \pm 12.5$ \\
\hline Cover crop + tailwater pond & $105.4 \pm 22.1$ & $0.3 \pm 0.1$ & $22.2 \pm 5.0$ & $1.3 \pm 0.2$ & $80.1 \pm 14.2$ & $166.5 \pm 57.9$ & $38.1 \pm 12.5$ \\
\hline Cover crop + tailwater pond + & $105.4 \pm 22.1$ & $0.0 \pm 0.0$ & $16.1 \pm 3.8$ & $0.6 \pm 0.1$ & $67.8 \pm 11.6$ & $166.5 \pm 57.9$ & $38.1 \pm 12.5$ \\
\hline
\end{tabular}
return

field the second year) at $1.43 \% \mathrm{~N}$, could have contributed $>112 \mathrm{~kg} \mathrm{~N} \mathrm{ha}^{-1}$ (100 lb N ac${ }^{-1}$ ) for $\mathrm{N}$ mineralization. This would also mean that $>3.4 \mathrm{Mg} \mathrm{Cha}^{-1}\left(>1.5\right.$ tn $\mathrm{C} \mathrm{ac}^{-1}$ ) of plant material would have been decomposing, yet $\mathrm{CO}_{2}-\mathrm{C}$ emissions were substantially lower than the year with the healthy crop. An alternative explanation for the higher $\mathrm{N}_{2} \mathrm{O}-\mathrm{N}$ emissions could be lower $\mathrm{N}$ uptake given the missing plants. Lower $\mathrm{N}$ uptake implies less $\mathrm{C}$ fixation, root growth, and in turn less root $\mathrm{C}$ turnover, respiration in the soil, and thus lower $\mathrm{CO}_{2}-\mathrm{C}$ emissions. It should be noted that the soil $\mathrm{NO}_{3}^{-}-\mathrm{N}$ pool at the end of both production seasons was similar, suggesting that tomatoes in the second year assimilated the available $\mathrm{N}$, while much of it may have been lost to denitrification and leaching in the first year due at least in part to higher prevalence of disease.

Management Tradeoffs. When nutrient losses from the plot and field were extrapolated to the entire production area of the farm, a broader set of tradeoffs associated with these BMPs emerged (table 7). These calculations showed that using winter cover crops across the farm, without the other BMPs, decreased the farm's TSS and DRP losses and its soil $\mathrm{CO}_{2}$ emissions but substantially increased DOC losses and soil $\mathrm{N}_{2} \mathrm{O}$ emissions. Note that the increased $\mathrm{N}_{2} \mathrm{O}$ emissions ( $\mathrm{CO}_{2}$ equivalents) are minor compared to the reduction in $\mathrm{CO}_{2}$ emissions. With an addition of a tailwater pond, the farm's estimated TSS losses would be further reduced, but $\mathrm{NO}_{3}^{-}-\mathrm{N}$ and DOC losses would likely increase. Although the tailwater pond at times had higher localized rates of soil $\mathrm{N}_{2} \mathrm{O}$ emissions, when these values are extrapolated to the full production area of the farm, the increase is minor $(<1 \%)$ given the small area of the ponds $(0.6 \mathrm{ha}[1.5 \mathrm{ac}])$ compared to the rest of the acreage. The tailwater return system increased the reduction of TSS by only $1 \%$ but greatly reduced $\mathrm{NO}_{3}^{-}-\mathrm{N}$, DRP, and DOC losses, with essentially no effect on soil $\mathrm{N}_{2} \mathrm{O}$ and $\mathrm{CO}_{2}$ emissions.

Thus winter cover crops alone may be an effective BMP for reducing some environmental impacts, but the farm benefits more from the addition of a tailwater pond with a tailwater return system. This exercise in scaling up from plot- to farm-level data suggests that further data collection (especially to capture extreme events), replication of these management options on multiple farms to allow for statistical analysis, and modeling over longer periods of time would help farmers make decisions about which BMPs to implement. Heavy rainfall and flooding is an example of an extreme event that influences the design of BMPs. During Rainfall $\mathrm{Y} 1$, runoff from rainfall exceeded the capacity of both tailwater ponds, causing overflow and discharging an unknown amount of sediment and other nutrients into the adjacent slough. Larger tailwater ponds would have greater capacity to detain discharge but would reduce the area available for crop production. To detain all the stormwater during the peak period of rainfall during this event could have required as much as a 15-fold increase in pond size. Using both cover crops and a tailwater pond as BMPs may be a useful combination for such a situation, as cover crops will likely stabilize the soil, minimizing sediment loss when the capacity of the tailwater pond is exceeded.

The long-term management effort and financial costs must also be considered in the context of the relative environmental quality benefits of these BMPs. The tailwater pond requires annual dredging and redistribution of sediment, and without the addition of a continually operating pump to return irrigation water to the field, the relatively short detention times of small-scale tailwater systems appear to concentrate certain pollutants. Cover crop operations add additional costs in terms of seed, labor, machinery, fuel, and/or electricity. This additional mechanization also contributes to increased greenhouse gas emissions. Furthermore, organic farmers using cover crops risk problems with nutrient availability should management operations be delayed (e.g., late spring rains). Alternative nutrient inputs for organic vegetable production systems may be effective but expensive (Smukler et al. 2008). Adoption of alternative irrigation systems, such as drip lines, could substantially increase water-use efficiency and reduce nutrient losses from surface runoff, leaching, and gaseous emissions (Sanchez-Martin et al. 2008; Vazquez et al. 2005), but purchasing, maintaining, and installing drip lines is expensive (Rominger personal communication 2008).

\section{Summary and Conclusions}

This study showed that tailwater ponds with a return system are a key BMP for reducing environmental impacts in California organic vegetable production and that cover crops can provide additional or even complimentary benefits, if managed carefully. Scaling plot-level data to an entire farm can help illustrate the benefits or tradeoffs of various BMPs and enable farmers to make more informed management decisions. A more complete life cycle analysis of BMPs would further enable farmers to choose more environmentally appropriate methodologies. These BMPs require additional investment, labor, and inputs for which farmers are rarely compensated in California, and an accurate cost-benefit analysis is needed. It is clear, however, that these BMPs generate multiple environmental benefits across the organic 
farmscape and deserve more attention by both farmers and policymakers.

\section{Acknowledgements}

We greatly appreciate the cooperation from Bruce Rominger and Rominger Brothers Farms of Yolo County, California throughout this project. Funding was provided by the USDA Cooperative State Research, Education, and Extension Service Organic Agriculture Research and Education Initiative Award 04-51106-02242, the Milton D. and Mary Miller Plant Sciences Award, the Graduate Group of Ecology Block Grants and Jastro-Shields Awards, and the Achievement Rewards for College Scientists Foundation Scholarship.

\section{References}

Allen, R.G., L.S. Pereira, D. Raes, and M. Smith. 1998. Crop evapotranspiration - Guidelines for computing crop water requirements. Food and Agriculture Organization Irrigation and Drainage paper 56 FAO. Rome, Italy: Food and Agriculture Organization of the United Nations.

Andrews, W.F. 1972. Soil Survey of Yolo County, California. USDA Soil Conservation Service.

Aronsson, H., G. Torstensson, and L. Bergstrom. 2007. Leaching and crop uptake of N, P and K from organic and conventional cropping systems on a clay soil. Soil Use and Management 23:71-81.

AVRDC-The World Vegetable Center. 2010. AVRDC International Cooperators' Fact Sheet. http://www. avrdc.org/LC/tomato/stemrot.html.

Baggs, E.M., C.A. Watson, and R.M. Rees. 2000. The fate of nitrogen from incorporated cover crop and green manure residues. Nutrient Cycling in Agroecosystems 56:153-163

Bajwa, S.G., and M. Mozaffari. 2007. Effect of $\mathrm{N}$ availability on vegetative index of cotton canopy:A spatial regression approach. Transactions of the American Society of Agricultural and Biological Engineers 50:1883-1892.

Bajwa, S.G., and E.D.Vories. 2007. Spatial analysis of cotton (Gossypium hirsutum L.) canopy responses to irrigation in a moderately humid area. Irrigation Science 25:429-441.

Berg, R.D., and D.L. Carter. 1980. Furrow erosion and sediment losses on irrigated cropland. Journal of Soil and Water Conservation 35(6):267-270.

Berry, P.M., R. Sylvester-Bradley, L. Philipps, D.J. Hatch, S.P. Cuttle, F.W. Rayns, and P. Gosling. 2002. Is the productivity of organic farms restricted by the supply of available nitrogen? Soil Use and Management 18:248-255

Bjorneberg, D.L., D.T. Westermann, and J.K. Aase. 2002. Nutrient losses in surface irrigation runoff. Journal of Soil and Water Conservation 57(524):524-529.

Blake, G.R., and K.H.Hartge. 1986. Bulk Density. In Methods of Soil Analysis: Part 1. Physical and Mineralogical Methods, Monograph Number 9, 2nd Edition, A. Klute, ed., 364-367, Madison, WI: American Society of Agronomy, Inc.
Brye, K.R., J.M. Norman, L.G. Bundy, and S.T. Gower. 2001. Nitrogen and carbon leaching in agroecosystems and their role in denitrification potential. Journal of Environmental Quality 30:58-70.

Burger, M., and L.E. Jackson. 2003. Microbial immobilization of ammonium and nitrate in relation to ammonification and nitrification rates in organic and conventional cropping systems. Soil Biology \& Biochemistry 35:29-36.

Casanoves, F, R. Macchiavelli, and M. Balzarini. 2005. Error variation in multienvironment peanut trials: Within-trial spatial correlation and between-trial heterogeneity. Crop Science 45:1927-1933.

Clark, M.S., W.R. Horwath, C. Shennan, K.M. Scow, W.T Lanini, and H. Ferris. 1999. Nitrogen, weeds and water as yield-limiting factors in conventional, low-input, and organic tomato systems. Agriculture Ecosystems \& Environment 73:257-270.

Clesceri, L.S., A.E. Greenberg, and A.D. Eaton. 1998. Method 2540 B. (Total Solids), Method 2540 C. (Total Dissolved Solids) and Method 2540 D. (Total Suspended Solids) Standard Methods for the Examination of Water and Wastewater, 20th ed. Washington DC: American Public Health Association.

Dabney, S.M. 1998. Cover crop impacts on watershed hydrology. Journal of Soil and Water Conservation 53(3):207-213.

Dabney, S.M., J.A. Delgado, and D.W. Reeves. 2001. Using winter cover crops to improve soil and water quality. Communications in Soil Science and Plant Analysis 32:1221-1250.

Dale, V.H., and S. Polasky. 2007. Measures of the effects of agricultural practices on ecosystem services. Ecological Economics 64:286-296.

Davis, L. 1994. A Handbook of Constructed Wetlands A Guide to Creating Wetlands for: Agricultural Wastewater, Domestic Wastewater, Coal Mine Drainage, Stormwater in the Mid-Atlantic Region, Volume 1: General Considerations. Prepared for the USDA Natural Resources Conservation Service and the Environmental Protection Agency (EPA) Region III in cooperation with the Pennsylvania Department of Environmental Resources.

DeFries, R., G. Asner, and R. Houghton. 2004. Tradeoffs in land-use decisions: Towards a framework for assessing multiple ecosystem responses to land use change. In Ecosystems and Land Use Change, Vol. 153, ed. R. DeFries, et al.,1-12. Washington, DC: American Geophysical Union.

Eichler-Lobermann, B., S. Kohne, B. Kowalski, and E. Schnug. 2008. Effect of catch cropping on phosphorus bioavailability in comparison to organic and inorganic fertilization. Journal of Plant Nutrition 31:659-676.

Eshel, G., G.J. Levy, U. Mingelgrin, and M.J. Singer. 2004. Critical evaluation of the use of laser diffraction for particle-size distribution analysis. Soil Science Society of America Journal 68:736-743.

Foster, J.C. 1995. Soil nitrogen. In Methods in Applied Soil Microbiology and Biochemistry, ed. K. Alef and P. Nannipieri, 79-87. San Diego: Academic Press.

Forster, P., V. Ramaswamy, P. Artaxo, T. Berntsen, R. Betts, D. W. Fahey, J. Haywood, J. Lean, D.C. Lowe, G. Myhre, J. Nganga, R. Prinn, G. Raga, M. Schulz, and R. Van Dorland, ed. 2007. Changes in Atmospheric Constituents and in Radiative Forcing. Cambridge, United Kingdom and New York: Cambridge University Press.

Fujii, R., A.J. Ranalli, G.R. Aiken, and B.A. Bergamaschi. 1998. Dissolved Organic Carbon Concentrations and Compositions, and Trihalomethane Formation Potentials in Waters from Agricultural Peat Soils, Sacramento-San Joaquin Delta, California: Implications for DrinkingWater Quality. US Geological Survey.

Goncalves, E.,A.S.Aubyn, and A. Martins. 2007. Mixed spatial models for data analysis of yield on large grapevine selection field trials. Theoretical and Applied Genetics 115:653-663.

Harrison, J., and P. Matson. 2003. Patterns and controls of nitrous oxide emissions from waters draining a subtropical agricultural valley. Global Biogeochemical Cycles 17:1080.

Harrison, J.A., P.A. Matson, and S.E. Fendorf. 2005. Effects of a diel oxygen cycle on nitrogen transformations and greenhouse gas emissions in a eutrophied subtropical stream. Aquatic Sciences 67:308-315.

Hartz, T.K. 2006. Vegetable production best management practices to minimize nutrient loss. Horttechnology 16:398-403.

Helsel, D.R., and R.M. Hirsch. 1993. Statistical Methods in Water Resources. New York: Elsevier.

Hoffland, E., R. Vandenboogaard, J. Nelemans, and G. Findenegg. 1992. Biosynthesis and root exudation of citic and malic-acids in phosphate-starved rape plants. New Phytologist 122:675-680.

Hutchinson, G.L., and G.P. Livingston. 1993. Use of chamber systems to measure trace gas fluxes., In Agricultural ecosystem effects on trace gases and global climate change, Vol. ASA Special Publication no. 55, ed. D.E. Rolston. Madison, WI: American Society of Agronomy, Crop Science Society of America, Soil Science Society of America.

Jackson, L.E., I. Ramirez, R. Yokota, S.A. Fennimore, S.T. Koike, D.M. Henderson, W.E. Chaney, FJ. Calderon, and K. Klonsky. 2004. On-farm assessment of organic matter and tillage management on vegetable yield, soil, weeds, pests, and economics in California. Agriculture Ecosystems \& Environment 103:443-463.

Jackson, L.E., L.J. Wyland, and L.J. Stivers. 1993. Winter cover crops to minimize nitrate losses in intensive lettuce production. Journal of Agricultural Science 121:55-62.

Johnson, J.M.F., D.C. Reicosky, R.R. Allmaras, T.J. Sauer, R.T. Venterea, and C.J. Dell. 2005. Greenhouse gas 
contributions and mitigation potential of agriculture in the central USA. Soil \& Tillage Research 83:73-94.

Jordan, N., G. Boody, W. Broussard, J.D. Glover, D. Keeney, B.H. McCown, G. McIsaac, M. Muller, H. Murray, J. Neal, C. Pansing, R.E. Turner, K. Warner, and D. Wyse. 2007. Environment - sustainable development of the agricultural bio-economy. Science 316:1570-1571.

Joyce, B.A., W.W. Wallender, J.P. Mitchell, L.M. Huyck, S.R. Temple, P.N. Brostrom, and T.C. Hsiao. 2002. Infiltration and soil water storage under winter cover cropping in California's Sacramento Valley. Transactions of the American Society of Agricultural Engineers 45:315-326.

Kadlec, R.H. 2005. Nitrogen farming for pollution control. Journal of Environmental Science and Health Part a-Toxic/Hazardous Substances \& Environmental Engineering 40:1307-1330.

Kadlec, R.H., and R.L. Knight. 1996. Treatment Wetlands. New York: Lewis Publishers.

Kenward, M.G., and J.H. Roger. 1997. Small sample inference for fixed effects from restricted maximum likelihood. Biometrics 53:983-997.

Kong, A.Y.Y., J. Six, D.C. Bryant, R.F. Denison, and C. van Kessel. 2005. The relationship between carbon input, aggregation, and soil organic carbon stabilization in sustainable cropping systems. Soil Science Society of America Journal 69:1078-1085.

Lee, J.J., and D.L. Phillips. 1993. The effect of trends in tillage practices on erosion and carbon content of soils in the United-States Corn-Belt. Water Air and Soil Pollution 70:389-401.

Marschner, P., Z. Solaiman, and Z. Rengel. 2007. Brassica genotypes differ in growth, phosphorus uptake and rhizosphere properties under P-limiting conditions. Soil Biology \& Biochemistry 39:87-98.

McSwiney, C.P., and G.P. Robertson. 2005. Nonlinear response of $\mathrm{N}_{2} \mathrm{O}$ flux to incremental fertilizer addition in a continuous maize (Zea mays L.) cropping system. Global Change Biology 11:1712-1719.

Miranda, K.M., M.G. Espey, and D.A. Wink. 2001. A rapid, simple spectrophotometric method for simultaneous detection of nitrate and nitrite. Nitric Oxide-Biology and Chemistry 5:62-71.

Murphy, J., and J.P. Riley. 1958. A single-solution method for the determination of soluble phosphate in seawater. Journal of the Marine Biological Association of the United Kingdom 37:9-14.

Mutchler, C.K., and L.L.Mcdowell.1990.Soil loss from cotton with winter cover crops. Transactions of the American Society of Agricultural Engineers 33:432-436.

Nelson, N.O., and R.R. Janke. 2007. Phosphorus sources and management in organic production systems. Horttechnology 17:442-454.

Olsen, S.R., and L.E.Sommers. 1982. Phosphorus, In Methods of Soil Analysis: Part 2. Chemical and Microbiological Properties, ASA Monograph Number 9, ed. A.L. Page, 403-430. Madison, WI: American Society of Agronomy.
Rhoades, J.D. 1982. Soluble salts, In Methods of Soil Analysis: Part 2: Chemical and Microbiological Properties, ASA Monograph Number 9 ed.A.L. Page, 167-179. Madison, WI: American Society of Agronomy.

Robertson, G.P., E.A. Paul, and R.R. Harwood. 2000 Greenhouse gases in intensive agriculture: Contributions of individual gases to the radiative forcing of the atmosphere. Science 289:1922-1925.

Sanchez-Martin, L., A. Arce, A. Benito, L. Garcia-Torres, and A.Vallejo. 2008. Influence of drip and furrow irrigation systems on nitrogen oxide emissions from a horticultural crop. Soil Biology \& Biochemistry 40:1698-1706.

Sarkodie-Addo, J., H.C. Lee, and E.M. Baggs. 2003. Nitrous oxide emissions after application of inorganic fertilizer and incorporation of green manure residues. Soil Use and Management 19:331-339.

Saunders, D.L., and J. Kalff. 2001. Nitrogen retention in wetlands, lakes and rivers. Hydrobiologia 443:205-212.

Schwankl, L.J., T.L. Prichard, and B.R. Hanson. 2007.Tailwater Return Systems, Reducing Runoff From Irrigated Lands, Publication 8225. ANR University of California.

Self, S.G., and K.Y. Liang. 1987. Asymptotic properties of maximum-likelihood estimators and likelihood ratio tests under nonstandard conditions. Journal of the American Statistical Association 82:605-610.

Shipitalo, M.J., and W.M. Edwards. 1998. Runoff and erosion control with conservation tillage and reducedinput practices on cropped watersheds. Soil \& Tillage Research 46:1-12.

Siemens, J., and M. Kaupenjohann. 2004. Comparison of three methods for field measurement of solute leaching in a sandy soil. Soil Science Society of America Journal 68:1191-1196.

Sileika, A.S., and S. Guzys. 2003. Drainage runoff and migration of mineral elements in organic and conventional cropping systems. Agronomie 23:633-641.

Smukler, S.M., L.E. Jackson, L. Murphree, R. Yokota, S.T. Koike, and R.F. Smith. 2008. Transition to large-scale organic vegetable production in the Salinas Valley, California. Agriculture Ecosystems \& Environment 126:168-188

Snyder, R.L., M. Orang, K. Bali, and S. Eching. 2007. Basic Irrigation Scheduling (BIS) http://biomet.ucdavis.edu/ irrigation_scheduling/bis/BIS.htm.

Stark, J.M., and M.K. Firestone. 1995. Mechanisms for soilmoisture effects on activity of nitrifying bacteria.Applied and Environmental Microbiology 61:218-221.

Tanner, C.C., M.L. Nguyen, and J.P.S. Sukias. 2005. Nutrient removal by a constructed wetland treating subsurface drainage from grazed dairy pasture. Agriculture, Ecosystems \& Environment 105:145-162.

Tonitto, C., M.B. David, and L.E. Drinkwater. 2006. Replacing bare fallows with cover crops in fertilizerintensive cropping systems: A meta-analysis of crop yield and $\mathrm{N}$ dynamics. Agriculture Ecosystems \& Environment 112:58-72.

USSL (US Salinity Laboratory). 1954. $\mathrm{pH}$ reading of saturated soil paste. In Diagnosis and improvement of saline and alkali soils, USDA Agricultural Handbook 60 , ed. L.A. Richards, 102. Washington, DC: US Government Printing Office.

USDA. 1997. United States standards for grades of tomatoes for processing. Agricultural Marketing Service, Fruit and Vegetable Division, Fresh Products Branch.

Vazquez, N., A. Pardo, M.L. Suso, and M. Quemada. 2005. A methodology for measuring drainage and nitrate leaching in unevenly irrigated vegetable crops. Plant and Soil 269:297-308.

Wagenet, R. 1986. Water and Solute Flux. In Methods of Soil Analysis: Part 1. Physical and Mineralogical Methods ASA Monograph Number 9, 2nd Edition, ed. A. Klute, 10551085. Madison, WI: American Society of Agronomy.

Watson, C.A., D. Atkinson, P. Gosling, L.R. Jackson, and F.W. Rayns. 2002. Managing soil fertility in organic farming systems. Soil Use and Management 18:239-247.

Webster, C.P., M.A. Shepherd, K.W.T. Goulding, and E. Lord. 1993. Comparisons of methods for measuring the leaching of mineral nitrogen from arable land. European Journal of Soil Science 44:49-62.

Willson, T.C., E.A. Paul, and R.R. Harwood. 2001 Biologically active soil organic matter fractions in sustainable cropping systems. Applied Soil Ecology 16:63-76.

Wolfinger, R. 1993. Covariance structure selection in general mixed models. Communications in Statistics-Simulation and Computation 22:1079-1106.

Wyland, L.J., and L.E. Jackson. 1993. Evaluating Nitrate Recovery by Ion-Exchange Resin Bags. Soil Science Society of America Journal 57:1208-1211.

Wyland, L.J., L.E. Jackson, W.E. Chaney, K. Klonsky, S.T. Koike, and B. Kimple. 1996. Winter cover crops in a vegetable cropping system: Impacts on nitrate leaching, soil water, crop yield, pests and management costs. Agriculture Ecosystems \& Environment 59:1-17.

Yamamura, S., J. Bartram, M. Csanady, H. Gorchev, and A. Redekopp.2004.Drinking water guidelines and standards. Geneva, Switzerland:World Health Organization.

Zar, J. 1974. Biostatistical Analysis. Upper Saddle River, NJ: Simon \& Schuster.

Zoarelli, L., J.M. Scholberg, M.D. Dukes, and R. MunozCarpena. 2007. Monitoring of nitrate leaching in sandy soils: Comparison of three methods. Journal of Environmental Quality 36:953-962. 